\title{
Regulation of the expression of CLU isoforms in endometrial proliferative diseases
}

\author{
PAOLO FUZIO $^{1,2}$, ALESSIO VALLETTI ${ }^{2,3}$, ANNA NAPOLI ${ }^{4}$, GRAZIA NAPOLI $^{5}$, GENNARO CORMIO $^{6}$, \\ LUIGI SELVAGGI $^{6}$, SABINO LIUNI ${ }^{1}$, GRAZIANO PESOLE ${ }^{2,3}$, EUGENIO MAIORANO $^{4}$ and ELDA PERLINO ${ }^{1}$ \\ ${ }^{1}$ Institute of Biomedical Technologies, ITB-CNR, I-70126 Bari; ${ }^{2}$ Institute of Biomembranes and Bioenergetics, \\ IBBE-CNR, I-70126 Bari; ${ }^{3}$ Department of Biosciences, Biotechnology and Biopharmaceutics, I-70126 Bari; \\ ${ }^{4}$ Interdisciplinary Department of Medicine, University of Bari 'Aldo Moro', I-70124 Bari; ${ }^{5}$ Department of \\ Pathological Anatomy and Genetics, Hospital of SS. Annunziata, I-74100 Taranto; ${ }^{6}$ Department of \\ Biomedical Sciences and Human Oncology, DIMO, University of Bari 'Aldo Moro', I-70124 Bari, Italy
}

Received December 14, 2012; Accepted February 18, 2013

DOI: 10.3892/ijo.2013.1894

\begin{abstract}
Clusterin (CLU) is a nearly ubiquitous multifunctional protein synthesized in different functionally divergent isoforms, sCLU and nCLU, playing a crucial role by keeping a balance between cell proliferation and death. Studying in vivo CLU expression we found a higher mRNA expression both in neoplastic and hyperplastic tissues in comparison to normal endometria; in particular, by RT-qPCR we demonstrated an increase of the specific sCLU isoform in the neoplastic and hyperplastic endometrial diseases. On the contrary, no CLU increase was detected at the protein level. The CLU gene transcriptional activity was upregulated in the hyperplastic and neoplastic tissues, indicating the existence of a fine post-transcriptional regulation of CLU expression possibly responsible for the protein decrease in the malignant disease. A specific CLU immunoreactivity was present in all the endometrial glandular cells in comparison to the other cellular compartments where CLU immunoreactivity was lower or absent. In conclusion, our results suggest the existence of a complex regulatory mechanism of CLU gene expression during the progression from normal to malignant cells, possibly contributing to endometrial carcinogenesis. Moreover, the specific alteration of the sCLU:nCLU ratio associated with the pathological stage, suggests a possible usage of CLU as molecular biomarker for the diagnosis/prognosis of endometrial proliferative diseases.
\end{abstract}

\section{Introduction}

Since endometrial carcinoma is the most frequently diagnosed gynecologic pathology, studies aimed at understanding the

Correspondence to: Dr Elda Perlino, Institute of Biomedical Technologies, ITB-CNR, Via Amendola 122/D, I-70126 Bari, Italy E-mail: elda.perlino@ba.itb.cnr.it

Key words: nCLU, sCLU, isoform 11036, expression regulation, endometrial tissue molecular mechanisms that underlie the onset and progression of endometrial transformation, should be considered of the greatest importance. Endometrial tissue represents a very highly interactive system involving different cell types, which relies on a complex network of intercellular and intracellular signalling in which cell cycle proteins, estrogens, cytokines and growth factors play relevant roles $(1,2)$. Therefore, this system appears particularly suitable for solving the puzzling relationships between mitosis and timed programmed cell death as suggested by the very latest scientific observations. The clarification of such interactions should consider all factors that contribute to a correct and balanced cell cycle progression. In this regard, the specific function of hormones, growth factors, adhesion molecules and apoptotic factors which play important roles in endometrial biology still needs to be clarified.

Clusterin (CLU) is a glycoprotein with a nearly ubiquitous tissue distribution and involvement in biological processes ranging from neurodegeneration in Alzheimer's disease to cancer initiation and progression $(3,4)$. Indeed, CLU has been implicated in numerous physiologic and pathologic processes important for carcinogenesis and tumor growth, including apoptotic cell death, cell cycle regulation, DNA repair, cell adhesion, tissue remodelling, lipid transportation, membrane recycling and immune system regulation $(3,4)$. Unravelling the functions of CLU has been an elusive goal: as cited above, it has been ascribed to many, and sometimes contradictory, processes. Part of this ambiguity results from the existence of two functionally divergent isoforms: a glycosylated secreted heterodimer of approximately $80 \mathrm{kDa}$, sCLU and a $55 \mathrm{kDa}$ non-glycosylated nuclear form, nCLU. The sCLU isoform is the full-length secreted heterodimer with documented anti-apoptotic function. The shorter nCLU isoform is synthesized from an alternative transcription start site, does not undergo cleavage or extensive glycosylation, is reported to translocate from the cytoplasm to the nucleus following cytotoxic events and postulated to induce apoptosis $(4,5)$. While accumulating data identify mature sCLU as an inhibitor of apoptosis, precise site(s) of action and binding proteins remain poorly defined. Likewise, the mature sCLU has a cytoprotective function, while under certain conditions 
pro-apoptotic signals may induce the expression of the nCLU isoform (6,7). A third transcript, called isoform 11036, has been recently characterized in colon cancer, but up to now its functional role remains unclear (8).

Previous studies, not taking into account specific isoform expression, have shown an increased expression of CLU in several human tumour tissues such as prostate, breast, renal, ovarian, colon, cervix, lung and anaplastic large cell lymphoma (9-16), where either abnormal cell death or proliferation occur (17). Upregulation of CLU mRNAs and proteins are widespread phenomena in developmental and patho-physiological states, suggesting that the control of its expression levels is of pivotal importance. CLU expression increases in surviving cells following a variety of stressors, including cytotoxic chemotherapy, radiation, her $2 /$ neu blockade and androgen or estrogens withdrawal in hormone-dependent tumours, presumably as a pro-survival response (18). These findings further demonstrate that CLU is a cell survival gene upregulated by apoptotic triggers, and confers resistance when overexpressed, thereby identifying CLU as a therapeutic target for cancer (19). Recent experimental evidence seems to indicate that a balance between sCLU:nCLU in the cell dictates its fate and is critical for cancer survival and progression. Indeed, in preclinical models of prostate cancer, the sCLU antisense oligonucleotide improved the efficacy of chemotherapy, radiation and androgen withdrawal by inhibiting expression of CLU and enhancing the apoptotic response (20). In addition, preclinical activity has been reported in lung, renal cell, cervical and breast cancers $(9,10,12,15)$. On this basis, investigating the CLU expression and function in human endometrial cancer could provide a novel therapeutic target for this malignancy.

Even though previous papers demonstrated that CLU is an estrogen-regulated gene in rat endometrial adenocarcinoma cells (21), whether a similar regulation occurs also in human endometrium still remains to be investigated. In this light, CLU may represent a target gene that can be used to monitor changes that are responsible for the progression from normal to malignant endometrial tissue. To investigate the involvement of CLU in the modulation of cell proliferation, apoptosis and clinical outcome in endometrial cancer, we used an in vivo experimental system consisting of endometrial tissues, already characterized in our laboratory during recent years (22-36). We established here for the first time the differential expression of CLU isoforms in both physiological and pathological, hyperplastic and neoplastic human endometrial tissues.

A better understanding of the biological mechanisms responsible for the uncontrolled growth of hormonally regulated cancers such as endometrial carcinoma, is critical to devise novel effective diagnostic and/or prognostic biomarkers such as CLU, which can be potentially used as 'signatures' to predict the clinical transformation of the disease in its different progressive phases.

Moreover, since the suppression of the sCLU isoform expression renders human cancer cells sensitive to chemotherapeutic drug-mediated apoptosis, and it is currently an antisense target in clinical trials for prostate cancer, the long-term objective of our studies is to state CLU as a new targeted modulator of endometrial cell proliferation potentially useful to generate rationally designed drugs based on tissue specific expression, in order to control cancer cell proliferation.

\section{Materials and methods}

Patients. This study was carried out using 64 endometrial tissue specimens from patients (Table I) submitted to laparotomic hysterectomy at the Department of Gynecology, Obstetrics and Neonatology of the University of Bari (Italy). Informed consent was obtained for all patients before the surgery as approved by the Internal Review Board. Samples were collected immediately after surgical resection and stored at $-80^{\circ} \mathrm{C}$ until use.

Two subgroups of patients were identified: the first included 26 patients with normal endometria who underwent hysterectomy for different pathologic conditions not involving the endometrium, such as uterine prolapse, ovarian cysts or subserosal leiomyomata. Based on histological features, these were characterized as: normal proliferative endometria (N1-N11; median age at surgery: $45 \pm 3$ years), secretive endometria (S1-S9; median age at surgery: $48 \pm 3$ years) and atrophic endometria (A1-A6; median age at surgery: $57 \pm 8$ years).

The second subgroup included 21 patients affected by histologically identified endometrial hyperplasia. Specifically, there were 13 simple hyperplasias (H1-H13) and 8 complex hyperplasias with cytological atypia (AH1-AH8). The median age of patients with simple hyperplastic disease (H1-H13) at surgery was $52 \pm 9$ years and for the patients affected by hyperplasia with cytological atypia (AH1-AH8) was $63 \pm 12$ years.

The remaining patients included histologically proven endometrial proliferative diseases, whose stage and grade were assessed according to the International Federation of Gynecology and Obstetrics (FIGO) (37). Overall, 17 patients were affected by endometrial adenocarcinoma (K1-K17; median age at surgery: $67 \pm 15$ years) that were classified as follows: 14 endometrioid adenocarcinomas ( 7 well differentiated, G1; 5 moderately, G2; and 2 poorly differentiated, G3), 1 serous carcinoma (G3), 1 mucinous carcinoma (G1) and 1 clear cell carcinoma (G1). None of the patients received any treatment (radiotherapy, chemotherapy or hormone therapy) before surgery.

RNA extraction and northern blot analysis. Frozen tissue samples were pulverized and cellular RNA was extracted using the guanidinium isothiocyanate-cesium chloride procedure as previously described (22). Quantity and purity of nucleic acid preparations were determined using a NanoDrop ND-1000 UV-VIS spectrophotometer (Thermo Scientific, Wilmington, DE, USA). RNA quality was assessed with a BioAnalyzer 2100 (Agilent Technologies, Böblingen, Germany). Total RNA $(25 \mu \mathrm{g})$ isolated from the tissues was electrophoresed through $1 \%$ denaturing agarose gel containing $660 \mathrm{mmol} / 1$ formaldehyde, and transferred to a nylon membrane (Hybond $\mathrm{N}^{+}$; Amersham, Milan, Italy), and northern blot analysis of CLU mRNA was performed as previously described (22). Radiolabeled probes were generated using the Megaprime DNA labeling kit (Amersham), $100 \mu \mathrm{Ci}$ of $\alpha-\left[{ }^{32} \mathrm{P}\right]-\mathrm{dcTP}(3,000 \mathrm{Ci} / \mathrm{mmol}$, Amersham $)$ and $25 \mathrm{ng}$ of double-stranded 1,649 bp specific fragment encoding for the full-length human CLU cDNA (7) (nucleotides 52-1700 actually corresponding to NM_001831, GenBank).

The filters were prehybridized overnight at $42^{\circ} \mathrm{C}$ with a buffer consisting of $50 \%$ formamide, $5 \mathrm{X}$ Denhardt's solution ( $1 \%$ Ficoll $400,1 \%$ polyvinylpyrrolidone, $1 \%$ bovine serum albumin), 5X sodium chloride/sodium phosphate/ethylene- 
Table I. Clinical features of patients analyzed.

\begin{tabular}{|c|c|c|c|c|c|c|}
\hline Patients & $\begin{array}{c}\text { Age } \\
\text { (years) }\end{array}$ & $\begin{array}{c}\text { Post menopausal } \\
\text { age (years) }\end{array}$ & Histology & Grade & Stage & Assays \\
\hline N1 & 41 & - & Normal proliferative endometrium & - & - & RT-qPCR, IH, \\
\hline N2 & 54 & - & Normal proliferative endometrium & - & - & NB, RT-qPCR \\
\hline N3 & 47 & - & Normal proliferative endometrium & - & - & NB, RT-qPCR, IH, WB \\
\hline N4 & 44 & - & Normal proliferative endometrium & - & - & NB, RT-qPCR, IH, WB \\
\hline N5 & 43 & - & Normal proliferative endometrium & - & - & $\mathrm{NB}, \mathrm{WB}$ \\
\hline N6 & 44 & - & Normal proliferative endometrium & - & - & NB, RT-qPCR \\
\hline N7 & 44 & - & Normal proliferative endometrium & - & - & $\mathrm{IH}$ \\
\hline N8 & 43 & - & Normal proliferative endometrium & - & - & $\mathrm{NB}, \mathrm{IH}$ \\
\hline N9 & 46 & - & Normal proliferative endometrium & - & - & $\mathrm{NB}, \mathrm{IH}, \mathrm{R}$ \\
\hline N10 & 47 & - & Normal proliferative endometrium & - & - & $\mathrm{NB}, \mathrm{WB}, \mathrm{R}$ \\
\hline N11 & 43 & - & Normal proliferative endometrium & - & - & $\mathrm{NB}, \mathrm{WB}$ \\
\hline $\mathrm{S} 1$ & 50 & - & Secretive endometrium & - & - & $\mathrm{NB}, \mathrm{IH}, \mathrm{R}$ \\
\hline $\mathrm{S} 2$ & - & - & Secretive endometrium & - & - & NB, RT-qPCR, R \\
\hline $\mathrm{S} 3$ & 45 & - & Secretive endometrium & - & - & NB, RT-qPCR, IH, WB \\
\hline S4 & - & - & Secretive endometrium & - & - & NB, RT-qPCR, IH, R \\
\hline S5 & 50 & - & Secretive endometrium & - & - & NB, RT-qPCR, WB \\
\hline S6 & 45 & - & Secretive endometrium & - & - & $\mathrm{NB}, \mathrm{IH}, \mathrm{WB}$ \\
\hline S7 & 52 & - & Secretive endometrium & - & - & NB, RT-qPCR \\
\hline S8 & 44 & - & Secretive endometrium & - & - & $\mathrm{NB}, \mathrm{IH}$ \\
\hline S9 & 47 & - & Secretive endometrium & - & - & $\mathrm{NB}, \mathrm{WB}$ \\
\hline A1 & 59 & 7 & Atrophic endometrium & - & - & NB, RT-qPCR, IH \\
\hline A2 & 52 & 3 & Atrophic endometrium & - & - & $\mathrm{NB}, \mathrm{IH}, \mathrm{WB}$ \\
\hline A3 & 56 & 6 & Atrophic endometrium & - & - & NB, RT-qPCR, IH, WB \\
\hline A4 & 51 & 4 & Atrophic endometrium & - & - & NB, RT-qPCR, IH, WB \\
\hline A5 & 50 & - & Atrophic endometrium & - & - & NB, RT-qPCR, IH, R \\
\hline A6 & 72 & 17 & Atrophic endometrium & - & - & RT-qPCR, IH, R \\
\hline $\mathrm{H} 1$ & 50 & - & Simple hyperplasia & - & - & NB,RT-qPCR, IH \\
\hline $\mathrm{H} 2$ & 56 & 1 & Simple hyperplasia & - & - & NB, RT-qPCR \\
\hline H3 & 62 & 12 & Simple hyperplasia & - & - & NB, RT-qPCR \\
\hline $\mathrm{H} 4$ & 72 & 22 & Simple hyperplasia & - & - & NB, RT-qPCR \\
\hline H5 & 45 & - & Simple hyperplasia & - & - & $\mathrm{NB}, \mathrm{R}$ \\
\hline H6 & 54 & 9 & Simple hyperplasia & - & - & $\mathrm{NB}, \mathrm{IH}$ \\
\hline $\mathrm{H} 7$ & 51 & - & Simple hyperplasia & - & - & $\mathrm{NB}, \mathrm{IH}$ \\
\hline $\mathrm{H} 8$ & 43 & - & Simple hyperplasia & - & - & NB, RT-qPCR \\
\hline H9 & 35 & - & Simple hyperplasia & - & - & $\mathrm{NB}, \mathrm{R}, \mathrm{WB}$ \\
\hline $\mathrm{H} 10$ & 52 & 2 & Simple hyperplasia & - & - & $\mathrm{NB}, \mathrm{IH}$ \\
\hline H11 & 50 & - & Simple hyperplasia & - & - & $\mathrm{NB}, \mathrm{R}$ \\
\hline H12 & 60 & 4 months & Simple hyperplasia & - & - & IH, WB \\
\hline H13 & 50 & - & Simple hyperplasia & - & - & $\mathrm{IH}$ \\
\hline AH1 & 49 & - & Atypical hyperplasia & - & - & $\mathrm{NB}, \mathrm{IH}$ \\
\hline $\mathrm{AH} 2$ & 62 & 12 & Atypical hyperplasia & - & - & NB, RT-qPCR \\
\hline $\mathrm{AH} 3$ & 55 & 2 & Atypical hyperplasia & - & - & NB, RT-qPCR \\
\hline AH4 & 76 & 26 & Atypical hyperplasia & - & - & NB, RT-qPCR \\
\hline AH5 & 83 & 33 & Atypical hyperplasia & - & - & NB, RT-qPCR \\
\hline AH6 & 61 & 4 & Atypical hyperplasia & - & - & $\mathrm{IH}$ \\
\hline $\mathrm{AH} 7$ & 71 & 31 & Atypical hyperplasia & - & - & $\mathrm{IH}$ \\
\hline AH8 & 49 & - & Atypical hyperplasia & - & - & $\mathrm{IH}$ \\
\hline
\end{tabular}


Table I. Continued.

\begin{tabular}{|c|c|c|c|c|c|c|}
\hline Patients & $\begin{array}{c}\text { Age } \\
\text { (years) }\end{array}$ & $\begin{array}{l}\text { Post menopausal } \\
\text { age (years) }\end{array}$ & Histology & Grade & Stage & Assays \\
\hline K1 & 85 & 34 & Mucinous adenocarcinoma & 1 & $1 b$ & NB, RT-qPCR \\
\hline K2 & 65 & 11 & Endometrioid adenocarcinoma & 1 & $1 \mathrm{c}$ & NB, RT-qPCR, WB \\
\hline K3 & 65 & 10 & Endometrioid adenocarcinoma & 1 & $1 \mathrm{c}$ & NB, RT-qPCR, WB, R \\
\hline K4 & 67 & 18 & Endometrioid adenocarcinoma & 1 & $1 \mathrm{c}$ & NB, RT-qPCR \\
\hline K5 & 73 & 31 & Endometrioid adenocarcinoma & 1 & $1 \mathrm{c}$ & NB, RT-qPCR, IH, WB \\
\hline K6 & 65 & 25 & Endometrioid adenocarcinoma & 1 & $4 b$ & NB, RT-qPCR, WB \\
\hline K7 & 68 & 12 & Endometrioid adenocarcinoma & 1 & $1 b$ & $\mathrm{NB}, \mathrm{WB}, \mathrm{R}$ \\
\hline K8 & 72 & 22 & Clear cell carcinoma & 1 & $1 \mathrm{~b}$ & NB, RT-qPCR, IH \\
\hline K9 & 50 & - & Endometrioid adenocarcinoma & 1 & $1 b$ & $\mathrm{IH}, \mathrm{R}$ \\
\hline K10 & 69 & 17 & Endometrioid adenocarcinoma & 2 & $1 \mathrm{c}$ & $\mathrm{NB}, \mathrm{IH}$ \\
\hline K11 & 51 & 3 & Endometrioid adenocarcinoma & 2 & $1 \mathrm{c}$ & $\mathrm{NB}, \mathrm{IH}, \mathrm{WB}$ \\
\hline K12 & 74 & 22 & Endometrioid adenocarcinoma & 2 & $1 \mathrm{c}$ & NB, RT-qPCR \\
\hline K13 & 65 & 15 & Endometrioid adenocarcinoma & 2 & $1 \mathrm{~b}$ & $\mathrm{NB}, \mathrm{IH}, \mathrm{R}$ \\
\hline K14 & 59 & 6 & Endometrioid adenocarcinoma & 2 & $3 \mathrm{a}$ & $\mathrm{IH}, \mathrm{WB}$ \\
\hline K15 & 57 & 9 & Serous adenocarcinoma & 3 & $1 \mathrm{c}$ & NB, RT-qPCR, WB \\
\hline K16 & 76 & 22 & Endometrioid adenocarcinoma & 3 & $1 \mathrm{c}$ & $\mathrm{NB}, \mathrm{IH}$ \\
\hline K17 & 74 & 14 & Endometrioid adenocarcinoma & 3 & $2 \mathrm{a}$ & $\mathrm{NB}, \mathrm{IH}, \mathrm{WB}$ \\
\hline
\end{tabular}

-, Data unknown; NB, northern blot analysis; RT-qPCR, real-time PCR; IH, immunohistochemistry; WB, western blot analysis; R, run-on.

diaminetetraacetic acid (SSPE) $(3 \mathrm{~mol} / \mathrm{l} \mathrm{NaCl}, 200 \mathrm{mmol} / \mathrm{l}$ $\mathrm{Na}_{2} \mathrm{H}_{2} \mathrm{PO}_{4}$, pH 7.0, $19 \mathrm{mmol} / 1$ ethylenediaminetetraacetic acid), $0.5 \%$ sodium dodecyl sulphate (SDS) and $100 \mathrm{mg} / \mathrm{ml}$ of sonicated salmon sperm DNA. The filters were then hybridized for $20 \mathrm{~h}$ at $42^{\circ} \mathrm{C}$ by adding $3 \times 10^{6} \mathrm{cpm}$ of $\left[{ }^{32} \mathrm{P}\right]$-labeled probe $/ \mathrm{ml}$ to the prehybridization solution. Subsequently the filters were washed once with $2 \mathrm{X}$ SSPE, $0.1 \%$ SDS for $10 \mathrm{~min}$ at room temperature, once with $1 \mathrm{X} \mathrm{SSPE}, 0.1 \%$ SDS at $42^{\circ} \mathrm{C}$, followed by several washes up to $0.1 \mathrm{X}$ SSPE, $0.1 \%$ SDS at $65^{\circ} \mathrm{C}$ and, finally, exposed overnight or longer to Kodak X-Omat AR 5 film (Kodak, Rochester, NY, USA) at $-80^{\circ} \mathrm{C}$.

Quantitative analysis was performed by densitometric scanning of the autoradiographs using a Bio-Rad GS-700 Imaging Densitometer (Bio-Rad, Richmond, CA, USA); multiple exposures of the same northern blots in a linear range were performed. mRNA levels were normalized by using the 28S ribosomal RNA, a constitutively expressed gene (38). For this purpose, blots were stripped in $0.1 \%$ boiling SDS and re-probed with the radiolabeled $\left[{ }^{32} \mathrm{P}\right]-28 \mathrm{~S}$ cDNA probe. The ratio between the CLU mRNA levels and the 28S rRNA levels was calculated for each sample to take into account for differences in RNA loading. CLU mRNA levels in secretive, atrophic, neoplastic and hyperplastic endometria were calculated as percentage of normal proliferative endometria mRNA average levels, hybridized on the same filter and settled at 100 (arbitrary unit). The variability of CLU mRNA levels in proliferative endometrial tissue specimens, measured by comparing the percentage of mRNA level from different normal endometrial tissues present on the same filter, was always less than $10 \%$ in the different measurements. For each specimen, the mean value $( \pm$ SEM) of results obtained in at least three experiments was calculated.
HL60 cells and human liver. One sample of histologically proven normal human liver, obtained during cholecystectomy, was also included in this study and submitted to RNA extraction to use as positive control in the northern hybridization experiments (28).

Human promyelocytic leukemia HL60 cells were grown in RPMI-1640 (Gibco, Life Technologies, Milan, Italy), with $50 \mathrm{mg} / \mathrm{ml}$ gentamicin, $2 \mathrm{mmol} / 1$ glutamine and $15 \%$ inactivated fetal calf serum, at $37^{\circ} \mathrm{C}$ in presence of $5 \% \mathrm{CO}_{2}$. Total RNA from differentiated HL60 cells was extracted $24 \mathrm{~h}$ after incubation with $160 \mathrm{nmol} / 1 \mathrm{TPA}$ (or PMA phorbol-12-myristate13-acetate; Sigma) and used as negative control in the northern hybridization experiments (29).

RT-qPCR experiments. Total RNA from human endometrial tissues was extracted as described in the section RNA extraction and northern blot analysis. Parameters of total RNA were assessed as follows: quantification of RNA was carried out using NanoDrop ND-1000 (Thermo Scientific) spectrophotometer; the quality of RNA was evaluated on Agilent 2100 Bioanalyzer (Agilent Technologies, Santa Clara, CA, USA) using an RNA 6000 Nano chip kit, RNA ladder and Agilent analysis software (Agilent Technologies).

cDNA synthesis was performed from $1 \mu \mathrm{g}$ of total RNA using QuantiTect ${ }^{\circledR}$ Reverse Transcription kit (Qiagen). Variant-specific PCRs, using the cDNAs as templates, were performed using the GoTaq ${ }^{\circledR}$ Flexi DNA Polymerase (Promega). Variant-specific primer pairs were constructed with Primer3 software, combining specific forward primers located in the unique exons $1(1 \mathrm{a}, 1 \mathrm{~b}$ or $1 \mathrm{c})$ and the reverse primer located in exon 2 (Fig. 1A). The sequence of primers are listed in Fig. 1B. 
A
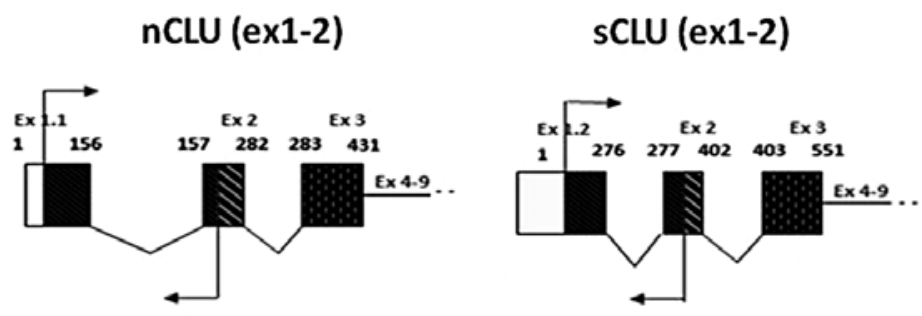

Isoform 11036 (ex1-2)

B

\begin{tabular}{ccc}
\hline Primer Name & Sequence 5' $\rightarrow \mathbf{3}^{\prime}$ & Amplicon Size \\
\hline $\begin{array}{c}\text { nCLU ex1.1 For } \\
\text { nCLU ex2 Rev }\end{array}$ & $\begin{array}{c}\text { GGTGTGTGCGCGAGCAGAG } \\
\text { GCCTCGGTCAGCGGCACC }\end{array}$ & $103 \mathrm{bp}$ \\
\hline $\begin{array}{c}\text { sCLU ex1.2 For } \\
\text { sCLU ex2 Rev }\end{array}$ & $\begin{array}{l}\text { CACTACTTCCACCCCTGAATG } \\
\text { TTGCACGCCTCTGAACTTGAC }\end{array}$ & $129 \mathrm{bp}$ \\
\hline $\begin{array}{c}\text { CLU Isoform 11036 ex1.3 For } \\
\text { CLU Isoform 11036 ex2 Rev }\end{array}$ & $\begin{array}{c}\text { AGGCACTCCTTGTTAATGTGCT } \\
\text { GCCTCCATTTGCCATCACAGA }\end{array}$ & $128 \mathrm{bp}$ \\
\hline $\begin{array}{c}\text { GADPH For } \\
\text { GADPH Rev }\end{array}$ & AACAGCGACACCCACTCCTC & $85 \mathrm{bp}$ \\
\hline & CATACCAGGAAATGAGCTTGACAA & \\
\end{tabular}

Figure 1. (A) Structure of nCLU, sCLU and isoform 11036 and (B) their respective primer sequences. The sequence of GAPDH primers pair used to normalize the CLU isoform expression in the endometrial tissues is also reported in (B).

A total of $1 \mu \mathrm{l}$ of each cDNA was used as template in qPCR assays, performed in triplicate on ABI PRISM 7900HT (Applied Biosystems) using the QuantiTect ${ }^{\circledR}$ SYBR-Green PCR Master mix (Qiagen). Amplification parameters were as follows: hot start at $95^{\circ} \mathrm{C}$ for $15 \mathrm{~min} ; 50$ cycles of amplification $\left(94^{\circ} \mathrm{C}\right.$ for $30 \mathrm{sec}, 64^{\circ} \mathrm{C}$ for $30 \mathrm{sec}, 72^{\circ} \mathrm{C}$ for $\left.40 \mathrm{sec}\right)$; dissociation curve step $\left(95^{\circ} \mathrm{C}\right.$ for $15 \mathrm{sec}, 60^{\circ} \mathrm{C}$ for $15 \mathrm{sec}, 95^{\circ} \mathrm{C}$ for $\left.15 \mathrm{sec}\right)$. Fluorescence raw data were exported from the SDS 2.2.1 software (Applied Biosystems) and analyzed with the DART-PCR Excel workbook (39). For each tissue, the relative expression ratio (rER) of different CLU transcripts was calculated applying the following formula: $\left[\left(1+\mathrm{E}_{\text {(calibrator) }}\right) \mathrm{Ct}_{\text {(calibrator) }} /\right.$ $\left.\left(1+\mathrm{E}_{\text {(target) }}\right) \wedge \mathrm{Ct}_{\text {(target) }}\right]$, where $\mathrm{E}$ is the average amplification efficiency calculated by DART-PCR for each primers pair and $\mathrm{Ct}$ is the average $\mathrm{Ct}$ obtained for the calibrator (proliferative endometrial tissues) and for the target (all endometrial tissue analyzed). Moreover, for each CLU isoform their relative expression ratio (rER) with respect to each endometrial tissues analyzed, was calculated by applying the following formula: $\left[\left(1+\mathrm{E}_{(\text {target })}\right) \wedge\left(\mathrm{Ct}_{\text {sample }}-\mathrm{Ct}_{\text {calibrator }}\right)_{\text {target }}\right] /\left[\left(1+\mathrm{E}_{(\mathrm{EC})}\right)\left(\mathrm{Ct}_{\text {sample }}-\right.\right.$ $\left.\left.\mathrm{Ct}_{\text {calibrator }}\right)_{\mathrm{EC}}\right]$, where $\mathrm{EC}$ is the endogenous control and the calibrator was arbitrary the nCLU. The average data from at least two independent experiments are reported.

Immunoblot analysis. Endometrial frozen tissue samples obtained from hysterectomy were homogenized in lysis buffer containing $0.1 \% \mathrm{SDS}, 1 \%$ Nonidet P-40, $50 \mathrm{mmol} / \mathrm{l}$ Tris- $\mathrm{HCl} \mathrm{pH} 7.5,150 \mathrm{mmol} / 1 \mathrm{NaCl}, 200 \mathrm{mmol} / 1 \mathrm{LiCl}$, $5 \mathrm{mmol} / 1 \mathrm{EDTA}, 10 \%$ glycerol, $10 \mu \mathrm{g} / \mathrm{ml}$ aprotinin, $120 \mu \mathrm{g} / \mathrm{ml}$ leupeptin, $170 \mu \mathrm{g} / \mathrm{ml}$ phenylmethylsulfonyl fluoride. The homogenate was sonicated for $20 \mathrm{sec}$ and then centrifuged for $30 \mathrm{~min}$ at $13,000 \mathrm{rpm}$ at $4^{\circ} \mathrm{C}$. The supernatants were centrifuged for $30 \mathrm{~min}$ at $13,000 \mathrm{rpm}$ at $4^{\circ} \mathrm{C}$ and collected. Tissue extracts $(100 \mu \mathrm{g})$ were electrophoresed on $10 \%$ SDS-polyacrylamide gel (PAGE) under reducing conditions and immunoblotting was carried out using either anti-CLU $\alpha$ chain antibody ( $1 \mu \mathrm{g} / \mathrm{ml})$ (Upstate Cell Signaling Solutions, Lake Placid, NJ, USA) or anti- $\beta$-tubulin antibody ( $2 \mu \mathrm{g} / \mathrm{ml}$ ) (Zymed Laboratories). In the first case the blots were incubated for $30 \mathrm{~min}$ at $4^{\circ} \mathrm{C}$ with a blocking solution composed of PBS pH $7.4\left(\mathrm{NaCl} 137 \mathrm{mM}, \mathrm{KCl} 3 \mathrm{mM}, \mathrm{NaHPO}_{4} 10 \mathrm{mM}\right.$, $\mathrm{KH}_{2} \mathrm{PO}_{4}$ ) containing $3 \%$ non-fat dry milk. Then the blots were incubated with the CLU $\alpha$ chain antibody for $16 \mathrm{~h}$ at $4^{\circ} \mathrm{C}$ in PBS containing 3\% non-fat dry milk. The membrane was then washed two times in water and incubated with mouse IgG horseradish-peroxidase-conjugate goat affinity-purified antibody (Bio-Rad) 1/3,000 diluted with PBS containing $3 \%$ non-fat dry milk for $90 \mathrm{~min}$ at room temperature. After two washes in water, one wash in PBS-T (PBS-Tween 0.05\%) and one wash in water again, the proteins were visualized using the Amersham enhanced chemiluminescent system according to the manufacturer's instructions. Protein levels were normalized using the constitutively expressed $\beta$-tubulin protein. For this purpose, the blots were stripped at $55^{\circ} \mathrm{C}$ for $20 \mathrm{~min}$ with stripping buffer [ $2 \%$ SDS, $10 \mathrm{mmol} / 1 \beta$-mercaptoethanol, $6 \mathrm{mmol} / \mathrm{l} \mathrm{Tris}-\mathrm{HCl}$ (pH 6.8)] and hybridized, with $2 \mu \mathrm{g} / \mathrm{ml}$ antibody to $\beta$-tubulin: the blots were incubated for $30 \mathrm{~min}$ at $4{ }^{\circ} \mathrm{C}$ with a blocking solution composed of TBS-T (20 mmol/1 Tris, $\mathrm{pH} 7.5,150 \mathrm{mmol} / 1 \mathrm{NaCl}, 0.2 \%$ Tween) containing 5\% non-fat dry milk. Then the blots were incubated for $16 \mathrm{~h}$ at $4^{\circ} \mathrm{C}$ with the $\beta$-tubulin antibody, in TBS-T containing 5\% non-fat dry milk. The membrane was then washed for $90 \mathrm{~min}$ at room temperature, in TBS-T and incubated with mouse IgG horseradish-peroxidase-conjugate goat affinity-purified antibody (Bio-Rad), diluted 1/3,000 in TBS-T containing 5\% non-fat dry milk. After two washes in TBS-T, the proteins were visualized using the Amersham enhanced chemiluminescent system according to the manufacturer's instructions. 
Densitometric values for immunoreactive bands were quantified by using a GS-700 Imaging Densitometer (Bio-Rad). CLU protein levels were calculated as percentage of the control (proliferative endometrium) taken as 100 in arbitrary units, after normalization using $\beta$-tubulin as control for protein loading. For each specimen, the mean value $( \pm$ SEM) of the results obtained in at least three experiments was calculated.

Nuclear run-on transcription assays. Isolation of nuclei and transcriptional rate assays were performed as previously described (35). The following linearized recombinant plasmids were used in the nuclear run-on analysis: the pIREShyg plasmid containing the 1,649 nt full length CLU cDNA (nucleotides 52-1700 actually corresponding to NM_001831, GenBank) linearized by Not1 digestion and the pABB plasmid containing the 28S cDNA (nucleotides 2435 to 2550) linearized by EcoR1 digestion.

After hybridization, the membranes were washed once in $2 \mathrm{X}$ SSPE, $0.1 \% \mathrm{SDS}$ for $10 \mathrm{~min}$ at $42^{\circ} \mathrm{C}$, twice in $1 \mathrm{X} \mathrm{SSPE}$, $0.1 \% \mathrm{SDS}$ for $10 \mathrm{~min}$ at $42^{\circ} \mathrm{C}$, twice in $0.5 \mathrm{X} \mathrm{SSPE}, 0.1 \%$ SDS for $10 \mathrm{~min}$ at $42^{\circ} \mathrm{C}$, once in $0.1 \mathrm{X} \mathrm{SSPE}, 0.1 \%$ SDS for $10 \mathrm{~min}$ at $50^{\circ} \mathrm{C}$ and then exposed to Kodak X-OMAT AR 5 film (Kodak).

Autoradiographs of the RNA-DNA hybrids obtained after 7 days exposure at $-80^{\circ} \mathrm{C}$ were analyzed using a GS-700 Imaging Densitometer (Bio-Rad). All values were standardized according to the 28S rRNA signal used as internal standard. The average of CLU transcriptional activity in proliferative endometrial samples derived from two patients was set at 100 (arbitrary units) and CLU transcriptional activity in secretive, atrophic, neoplastic and hyperplastic endometria was calculated as percentage of the proliferative endometrial transcriptional activity.

Histopathology and immunohistochemistry. The study material for histopathology included all surgical samples from which tissue fragments for the molecular investigations had been taken.

The surgical samples were fixed in $10 \%$ neutral buffered formalin for 12-24 h, embedded in paraffin, cut and stained with hematoxylin and eosin $(\mathrm{H} \& \mathrm{E})$. The histological preparations were reviewed by three pathologists (E. Maiorano, G. Napoli and A. Napoli) to compare the histological dating with the clinical dating in normal cycling women, to specify the histological subtype of endometrial carcinomas and define tumor grade.

From selected cases (see Table I) for which sufficient and representative amounts of tissues were available after morphological analysis, a single paraffin block per case was selected for immunostaining based on good morphological preservation. Thick sections (5 $\mu \mathrm{m})$ were cut, collected on positively-charged slides, dewaxed and rehydrated. Following quenching of endogenous peroxidase with $3 \% \mathrm{H}_{2} \mathrm{O}_{2}$ for $15 \mathrm{~min}$ at room temperature, the sections were immunostained for CLU and caspase-3 using a peroxidase-based detection system (En Vision, Dako, Glostrup, Denmark) with an automated immunostainer (Autostainer, Dako). Prior to the staining procedure, the sections to be incubated with anti-clusterin/anti-caspase-3 antibodies were immersed in $0.01 \mathrm{M}$ citrate buffer, $\mathrm{pH} 6.0$ and incubated at $98^{\circ} \mathrm{C}$ for $30 \mathrm{~min}$ in a water bath. Mouse monoclonal antibodies against clusterin and caspase-3 (Upstate Cell Signaling Solutions; clone: 41D, dilution 1:200) were used as primary antibodies with overnight incubations at $4^{\circ} \mathrm{C}$.
Control sections for specificity included staining of positive controls (normal and carcinomatous prostate) and negative control sections, which were incubated with the immunoglobulin fraction of normal mouse serum in place of the specific immunoreagent.

Evaluation of immunoreactivity. In all cases the immunoreactivity was independently evaluated by two pathologists (E. Maiorano and A. Napoli) by separately counting the relative number of immunoreactive superficial and glandular epithelial cells and stromal cells in 10 different microscopic fields, observed at $\mathrm{x} 400$ magnification; the extent of the immunoreactivity within each cell component (superficial vs. glandular epithelial cells vs. stromal cells), as the percentage of immunoreactive cells, was recorded for individual cases. In the cases of endometrial carcinoma, the immunoreactivity in superficial epithelial cells and in stromal cells was recorded to the cells adjacent to the tumor in the surrounding residual structures, and only the immunoreactivity of glandular epithelial cells is referred to as neoplastic cells.

Statistical analysis. For each histological endometrial group data are reported as the mean \pm SEM. Statistical analysis was performed using the ANOVA followed by Duncan's post hoc test. All experiments were repeated at least three times.

\section{Results}

CLU mRNA expression in the endometrial tissues. Steady state levels of total CLU mRNA were quantified by northern hybridization experiments by using total RNA isolated from 23 physiological endometrial tissues samples ( 9 proliferative, 9 secretive and 5 atrophic endometrial tissues), 16 neoplastic and 15 hyperplastic endometrial tissues (see Table I). Fig. 2 shows the results of a typical northern hybridization analysis carried out using the full length CLU cDNA probe able to hybridize all CLU isoforms (7). Total RNA extracted from HL60 cells (lane 1) was used as negative control of CLU mRNA expression and total RNA extracted from human liver (lane 2) was used as positive control (Fig. 2A). Under our hybridation and washing conditions (see Materials and methods) a $1.9 \mathrm{~kb}$ long transcript was present in all the samples, corresponding to the specific endometrial CLU mRNA (2), in agreement also with human prostate studies $(13,40)$. CLU mRNA showed a variable expression level in the different physiological (lanes 6-12) and pathological endometrial conditions (lanes 13-20) in comparison to the normal proliferative endometria (lanes 3-5).

To normalize the differences due to the experimental procedure, such as mRNA loading and transfer, the blots were de-hybridized and re-hybridized again with the human $28 \mathrm{~S}$ rRNA cDNA probe. In this way the possible differences due to the experimental procedure could be taken into account by calculating for each sample the ratio between the CLU mRNA band and the 28S rRNA signal. Hereafter, CLU mRNA levels in the endometrial tissues were calculated as the percentage of proliferative endometrial CLU mRNA levels, present on the same filter. The mean values of at least three separate measurements for each patient were recorded and the average values of the various specimens belonging to the same histological endometrial tissues group \pm SEM, were calculated (Fig. 2B). The 
A

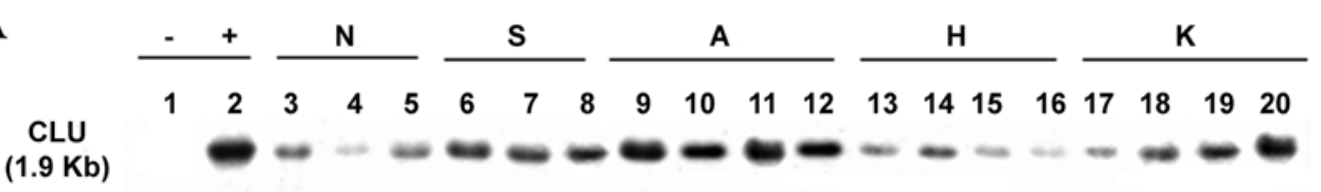

$28 \mathrm{~S}$

$(5.1 \mathrm{~Kb})$

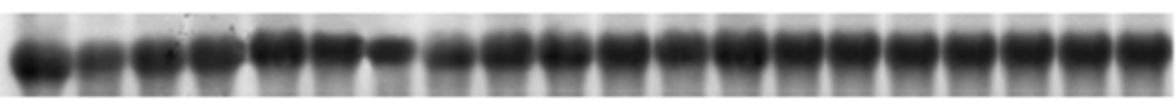

B

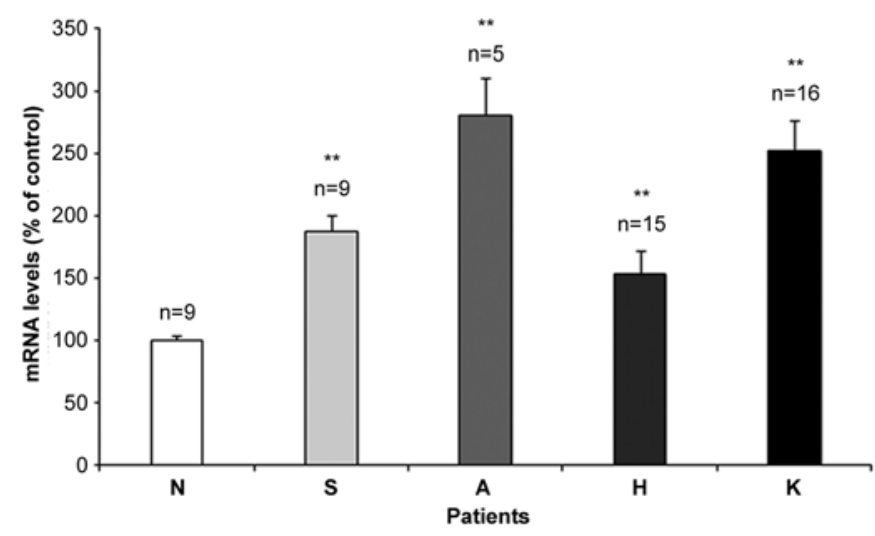

C

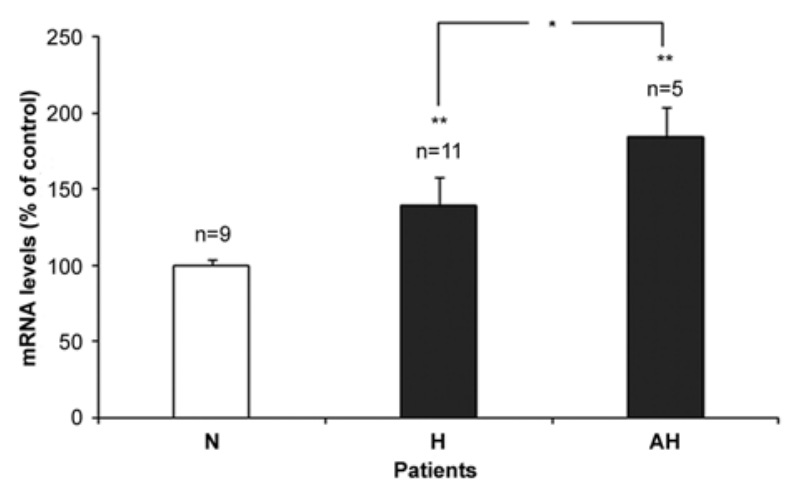

Figure 2. CLU mRNA expression in the endometrial tissues. (A) Total RNA was isolated from the endometrial tissue samples indicated in Table I. Total RNA $(25 \mu \mathrm{g})$ was used; lane 1, RNA from HL60 cells was used as negative control; lane 2, RNA from human liver was used as positive control; lanes 3-5, RNA isolated from 3 patients with normal proliferative endometrial tissues; lanes 6-8, RNA isolated from 3 patients with secretive endometrial tissues; lanes 9-12, RNA isolated from 4 patients with atrophic endometrial tissues; lanes 13-16, RNA isolated from 4 patients with hyperplastic endometrial tissues; lanes 17-20, RNA isolated from 4 patients with neoplastic endometrial tissues. To normalize the amount of total RNA in each sample, the blot was stripped and re-hybridized again using a $28 \mathrm{~S}$ rRNA cDNA probe. (B) The average \pm SEM of CLU mRNA levels in the 9 secretive (S), 5 atrophic (A), 16 hyperplastic (H) and 16 neoplastic (K) endometrial tissue samples were calculated as percentage of N. (C) The 16 patients with hyperplastic endometria were divided into two groups: the first included 11 patients affected by simple hyperplasia $(\mathrm{H})$; the second included 5 patients affected by atypical hyperplasia $(\mathrm{AH})$ and $\mathrm{mRNA}$ levels were calculated as percentage of $\mathrm{N}$. Mean values \pm SEM from at least three different experiments are illustrated. Error bars indicate $\mathrm{SEM} .{ }^{*} \mathrm{P}<0.05,{ }^{* * *} \mathrm{P}<0.01$.

semi-quantitative analysis of CLU mRNA expression shows an increase in both normal and diseased endometrial tissues.

With regard to normal endometrial tissues the steady-state CLU mRNA level was upregulated in $86 \%$ of secretive and in $100 \%$ of atrophic endometrial samples, when compared to the normal proliferative endometria. In fact, the CLU mRNA expression in secretive tissue samples ranged from $119 \pm 16 \%$ to $298 \pm 7 \%$, with an average value of $188 \pm 13 \%$, while CLU mRNA levels in the atrophic samples ranged between $187 \pm 13 \%$ and $408 \pm 20 \%$, with a mean percentage value of $281 \pm 30 \%$. This upregulation resulted statistically significant $(\mathrm{p}<0.01)$ both in secretive and atrophic endometrial tissues in comparison to the normal proliferative tissues.

Considering the neoplastic endometrial tissues, our analysis showed an increased CLU mRNA level in 94\% of endometrial carcinoma $(\mathrm{K})$ samples. The expression of CLU mRNA in cancer tissues ranged from $98 \pm 21 \%$ to $474 \pm 8 \%$ with a percentage average value of $252 \pm 25 \%$ and this increase was statistically significant $(\mathrm{p}<0.01)$ in comparison to the normal control. An increased steady state CLU mRNA level $(153 \pm 19 \%)$ was detected also in $62 \%$ of total endometrial hyperplastic samples and this increase was statistically significant $(\mathrm{p}<0.01)$ in comparison to the normal endometrial tissues. Moreover, we evaluated the CLU mRNA expression in the different types of endometrial hyperplasia based on hystopathological examina- tion (Fig. 2C): 11 hyperplasia without cytological atypia $(\mathrm{H})$ and 5 hyperplasia with atypia (AH). The expression of CLU mRNA in the hyperplasia without cytological atypia $(\mathrm{H})$ ranged between $98 \pm 7 \%$ and $243 \pm 30 \%$ with a percentage average value of $139 \pm 19 \%$. In the 5 hyperplasia with atypia (AH) the CLU mRNA levels ranged from $99 \pm 12 \%$ up to $252 \pm 19 \%$ with an average value of $184 \pm 20 \%$. The increase of the CLU mRNA for both these categories was statistically significant $(p<0.01)$ in comparison to the normal endometrial tissues. The CLU increase observed in endometrial hyperplasia with atypia $(\mathrm{AH})$ was statistically $(\mathrm{p}<0.05)$ higher than the increase measured in the simple hyperplasia. This result seems to attest a benign proliferative origin for the hyperpastic disease even in the presence of atypia, whereas it was demonstrated that $30 \%$ of cases of hyperplasia with atypia evolve in endometrial carcinoma (41). In conclusion, total CLU mRNA expression appears to progressively increase in both normal differentiated atrophic and secretive tissues, and proliferative disease such as hyperplasia and carcinoma, in comparison to the normal endometrial tissue.

CLU expression and tumor progression. Since gene expression profiling of CLU in prostate cancer, performed with conventional techniques such as northern hybridization, provides reliable prognostic prediction of prostate cancer when used in combination with standard clinical information, such as histological 
A

\begin{tabular}{ll} 
& \\
\hline FIGO Stage: & $\mathrm{I}=13$ \\
& $\mathrm{II}=1$ \\
& $\mathrm{IV}=1$ \\
\hline Grading: & $\mathrm{G} 1=8$ \\
& $\mathrm{G} 2=4$ \\
& $\mathrm{G} 3=3$ \\
\hline
\end{tabular}

B

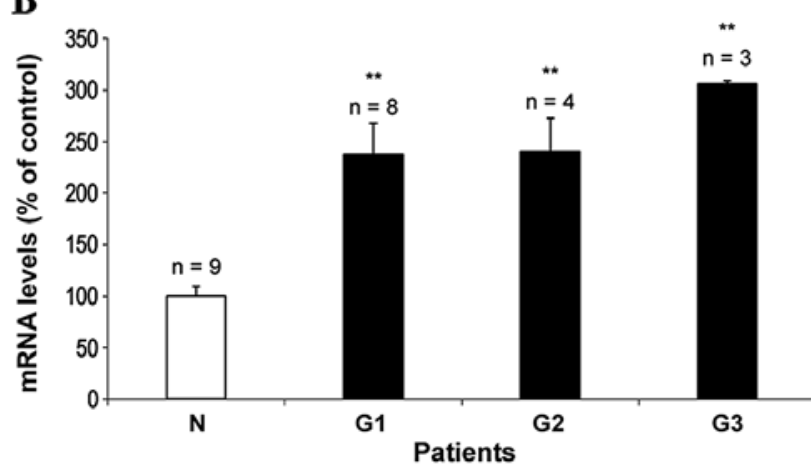

C

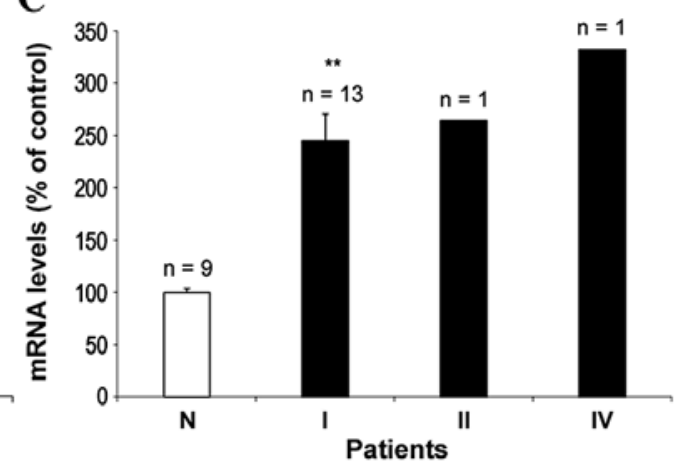

Figure 3. Association between CLU mRNA expression and clinical progression. (A) The $15 \mathrm{~K}$ neoplastic endometrial samples described in Table I were divided in three groups based on the degree of tumor differentiation according to FIGO and staging. The first included 8 patients with well differentiated (G1) endometrial carcinoma; the second included 4 patients with moderately differentiated (G2) endometrial carcinoma; the third included 3 patients with poorly differentiated (G3) endometrial carcinoma (B). The second included 1 patient with stage II endometrial carcinoma and the third included 1 patient affected by stage IV endometrial carcinoma. N, normal proliferative tissue specimens (C). The CLU mRNA level was calculated as percentage compared to the normal proliferative endometria $(\mathrm{N})$. Error bars indicate SEM. ${ }^{* *} \mathrm{P}<0.01$.

and tumor stage (13), we decided to investigate the correlation between CLU mRNA expression and endometrial carcinoma clinical progression (Fig. 3). For this purpose we evaluated CLU mRNA levels in neoplastic endometrial samples classified by histological tumor grade and pathological stage, based on the FIGO system (37) (Fig. 3A). Fig. 3B illustrates CLU mRNA levels in endometrial neoplastic tissues, classified according to $G$ grade. A statistically significantly $(\mathrm{p}<0.01)$ increase $(306 \pm 3 \%)$ of CLU mRNA levels was detected in the 3 patients affected by poorly-differentiated endometrial carcinoma (G3), suggesting a direct correlation between the CLU mRNA level and the tumour progression. This trend seems to be confirmed by the analysis between CLU mRNA expression and the tumor stage (Fig. 3C) whereas, in consideration of the relatively low number of stage II and stage IV samples $(n=1)$ and the absence of stage III cases, a statistical evaluation was not feasible.

In conclusion, since the statistical analysis were not powerful enough, due to the limited number of cases, we could not demonstrate a clear association between CLU expression and tumor grade and/or stage in endometrial carcinoma.

Analysis of CLU mRNA variants. Since it was suggested that sCLU:nCLU cellular balance is critical for cancer establishment and progression (4) we decided to characterize the different CLU mRNA variants present in the endometrial tissues with the aim of correlating these isoforms to the different physiopathological stage of the endometrial tissue.

To identify all possible novel CLU variants, we first inspected the CLU entries in the ASPicDB, the Alternative Splicing Prediction Data Base (http://t.caspur.it/ASPicDB/index. php) $(42,43)$. These inspections revealed multiple possible CLU mRNA variants, three of which (identified by the Signature ID (44) c7175b345e:9, 1057fea355:9, 8031cbleal:9, and corresponding to nCLU, sCLU and isoform 11036, respectively) stood out by having substantially more sequence support than the rest. These three variants all contain nine exons, and each of them presents a unique exon 1 and shares the remaining 2-9 exons (Fig. 1A). By RT-PCR analysis followed by sequencing experiments, we have shown for the first time that all the three
CLU mRNA variants are expressed in the endometrial tissues in vivo. Moreover, by using the specific CLU primers shown in the Fig. 1B, we did not observe any additional bands except the three variant-specific RT-PCRs.

To measure the quantitative variation of CLU isoform expression in the different physio-pathological endometrial stages for possible correlation of the expression of each CLU isoform to the specific condition, we carried out CLU isoform mRNA expression analyses by RT-qPCR. The primers, firstly validated by PCR, were used to assess the CLU isoform expression level in the different biopsy specimens obtained from the human endometrial tissue: normal proliferative phase (N1-N4, N6), normal secretive (S2-S5, S7), atrophic (A1, A3-A6), hyperplastic (H1-H4,H8, AH2-AH5), neoplastic (K1-K6, K8, K12,K15) tissues (see Table I). The normal follicular tissues (N1) was selected as calibrator of the RT-qPCR experiments, by means of a preliminary experiment, with GAPDH used for normalization. Fig. 4A shows the range and the mean value of expression for each CLU isoform in the different endometrial tissues. The nCLU mRNA expression (Fig. 4B) in the secretive phase (S) was lower $(56 \pm 2 \%)$ than the normal follicular tissue (N). On the contrary, the average percentage of nCLU mRNA expression was 10 times higher $(1,094 \pm 16 \%)$ in the atrophic endometrium (A) than the normal follicular phase (N). In both types of hyperplastic endometrial tissue samples $(\mathrm{H}$ and $\mathrm{AH})$, the percentage of nCLU mRNA expression was higher $(156 \pm 4 \%$ and $630 \pm 17 \%$, respectively) in comparison to the normal follicular endometria $(\mathrm{N})$.

In the neoplastic endometrial tissue samples $(\mathrm{K})$ the average percentage of nCLU mRNA expression was lower $(80 \pm 3 \%)$ than the normal follicular tissues $(\mathrm{N})$. The sCLU mRNA expression (Fig. 4C) in the secretive endometrium (S) amounted to $879 \%( \pm 6)$ in comparison to the normal follicular tissues; in the atrophic endometrium (A) the sCLU mRNA expression was higher $(3,851 \pm 26 \%)$ than the normal follicular tissues. sCLU mRNA expression in the endometrial hyperplasia was higher in both hyperplastic tissues without $(\mathrm{H})$ and with atypia $(\mathrm{AH})(1,226 \pm 9 \%$ and $10,138 \pm 63 \%$, respectively) than the normal follicular endometrium $(\mathrm{N})$. In the neoplastic 
A

\begin{tabular}{|c|c|c|c|}
\hline & \% nCLU expression & $\%$ sCLU expression & \% Isoform 11036 expression \\
\hline $\begin{array}{c}\text { Secretive } \\
\text { endometrium }\end{array}$ & $\begin{array}{c}(30 \pm 3 \%) \div(74 \pm 2 \%) \\
56 \pm \mathbf{2} \%\end{array}$ & $\begin{array}{c}(671 \pm 3 \%) \div(1075 \pm 9 \%) \\
879 \pm 6 \%\end{array}$ & $\begin{array}{c}(248 \pm 1 \%) \div(902 \pm 3 \%) \\
624 \pm 7 \%\end{array}$ \\
\hline $\begin{array}{c}\text { Atrophic } \\
\text { endometrium }\end{array}$ & $\begin{array}{c}(923 \pm 9 \%) \div(1290 \pm 2 \%) \\
\mathbf{1 0 9 4} \pm \mathbf{1 6 \%}\end{array}$ & $\begin{array}{c}(1159 \pm 11 \%) \div(3987 \pm 12 \%) \\
\mathbf{3 8 5 1} \pm \mathbf{2 6 \%} \%\end{array}$ & $\begin{array}{c}(497 \pm 18 \%) \div(4483 \pm 10 \%) \\
\mathbf{3 5 1 6} \pm \mathbf{2 7 \%} \% \\
\end{array}$ \\
\hline $\begin{array}{c}\text { Simple } \\
\text { hyperplasia }\end{array}$ & $\begin{array}{c}(88 \pm 9 \%) \div(252 \pm 7 \%) \\
156 \pm 4 \% \\
\end{array}$ & $\begin{array}{c}(750 \pm 10 \%) \div(1824 \pm 10 \%) \\
\mathbf{1 2 2 6} \pm \mathbf{9} \%\end{array}$ & $\begin{array}{c}(59 \pm 15 \%) \div(1930 \pm 13 \%) \\
\mathbf{7 4 7} \pm \mathbf{1 4} \%\end{array}$ \\
\hline $\begin{array}{c}\text { Atypical } \\
\text { hyperplasia }\end{array}$ & $\begin{array}{c}(63 \pm 16 \%) \div(2302 \pm 2 \%) \\
630 \pm 17 \%\end{array}$ & $\begin{array}{c}(1469 \pm 6 \%) \div(33829 \pm 3 \%) \\
10138 \pm 63 \%\end{array}$ & $\begin{array}{c}(611 \pm 1 \%) \div(20391 \pm 3 \%) \\
\mathbf{5 6 2 2} \pm \mathbf{5 0} \% \\
\end{array}$ \\
\hline $\begin{array}{c}\text { Neoplastic } \\
\text { endometrium }\end{array}$ & $\begin{array}{c}(923 \pm 9 \%) \div(1290 \pm 2 \%) \\
\mathbf{8 0} \pm \mathbf{3} \% \\
\end{array}$ & $\begin{array}{c}(923 \pm 9 \%) \div(1290 \pm 2 \%) \\
\mathbf{3 8 0 7} \pm \mathbf{2 7} \% \\
\end{array}$ & $\begin{array}{c}(923 \pm 9 \%) \div(1290 \pm 2 \%) \\
\mathbf{3 6 7 0} \pm \mathbf{2 4} \% \\
\end{array}$ \\
\hline
\end{tabular}

B

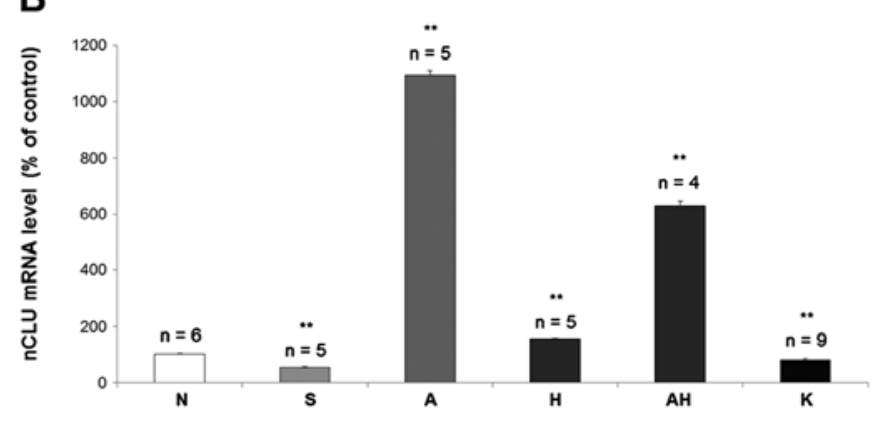

D

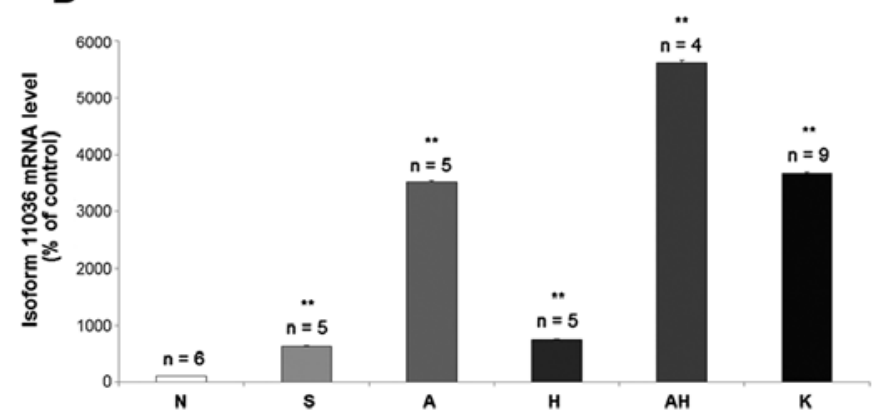

C

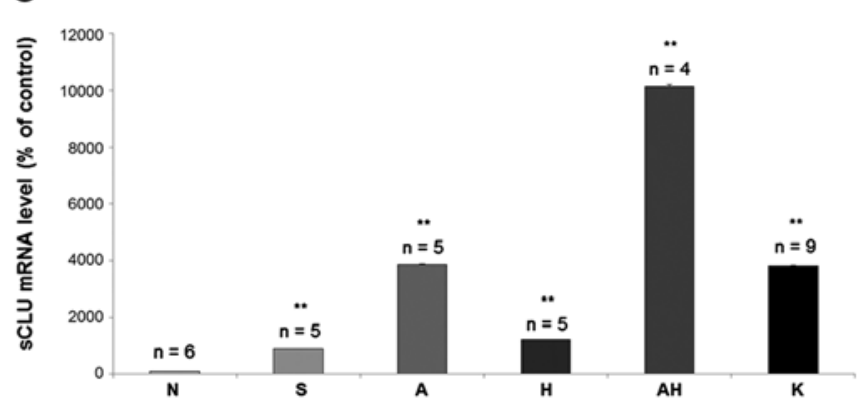

E

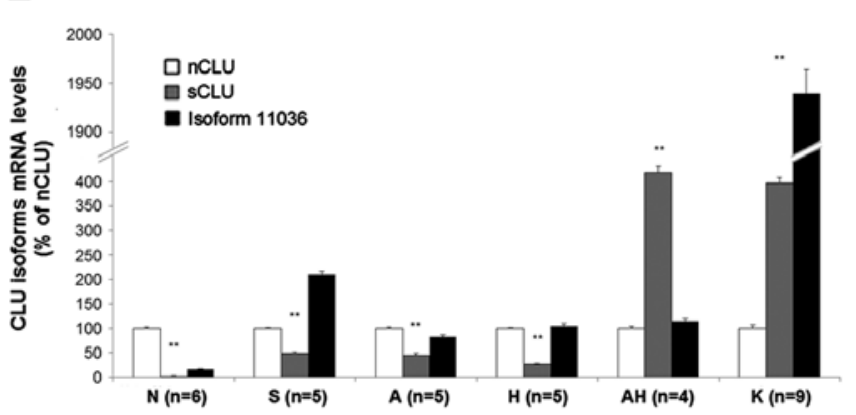

Figure 4. CLU isoforms expression. (A) The range and the mean value of expression for each CLU isoform in the different endometrial tissues was obtained by RT-qPCR. The percentage of each CLU isoform was measured in the secretive (S), atrophic (A), hyperplastic (I) and neoplastic (K) endometria in comparison to the normal proliferative tissue (N). (B) nCLU expression; (C) sCLU expression; (D) isoform 11036 expression. (E) sCLU and isoform 11036 expression levels were calculated as percentage of $\mathrm{nCLU}$ in the endometrial tissues. Error bars indicate SEM. ${ }^{* *} \mathrm{P}<0.01$.

endometrial tissue samples $(\mathrm{K})$ the sCLU mRNA expression increased up to $3,807 \pm 27 \%$ respect to normal endometrium (N). The isoform 11036 CLU mRNA level (Fig. 4D) resulted higher $(624 \pm 7 \%)$ in the secretive endometrium (S) than the normal follicular tissues; in the atrophic endometrium (A) it amounted to $3,516 \pm 27 \%$. In both types of hyperplastic endometrial tissue (without atypia, $\mathrm{H}$; or with atypia, $\mathrm{AH}$ ) the isoform 11036 CLU mRNA was higher $(747 \pm 14 \%$ and $5,622 \pm 50 \%$, respectively) than the normal follicular endometria $(\mathrm{N})$. In the neoplastic samples $(\mathrm{K})$ isoform $11036 \mathrm{CLU}$ mRNA was higher $(3,670 \pm 24 \%)$ than the normal follicular endometria $(\mathrm{N})$.

To provide data on the amount of the variation of expression for each CLU isoform in the different physiological and pathological stage, we analyzed the balance of the three isoforms in the different endometrial tissues. The identification of the specific relative ratio of expression of these three isoforms in the endometrial tissues may allow to identify a possible role of one of these isoforms during the different states of differentiation (follicular < secretive < atrophic) and/or its involvement in the tissue remodelling and/or block of cell progression. Moreover, the analysis of the ratio of the three isoforms may help to iden- tify a possible specific correlation with the physio-pathological stage or during the transition from the normal to the neoplastic transformation, possibly allowing us to use CLU as a biomarker for the diagnosis and/or prognosis of the endometrial proliferative disease. Fig. 4E shows the sCLU and isoform 11036 mRNA expression compared to the nCLU mRNA, taken as calibrator and arbitrarily set as $100 \%$. In the normal follicular phase (N) both the sCLU and isoform 11036 mRNA percentage of expression were lower $(2.5 \pm 1 \%$ and $16 \pm 1 \%$, respectively) than the nCLU mRNA expression. In the secretive endometrial tissue (S) the sCLU mRNA expression level was lower (49 $\pm 2 \%$ ) than the nCLU, while the isoform $11036 \mathrm{mRNA}$ expression was higher $(210 \pm 6 \%)$ than the nCLU. In the atrophic endometrial tissue (A) both the sCLU and isoform 11036 mRNA expression were lower ( $45 \pm 4 \%$ and $85 \pm 4 \%$, respectively) than the nCLU. In the hyperplastic endometrial tissue without cytological atypia $(\mathrm{H})$ the sCLU mRNA was lower $(26 \pm 2 \%)$ than the nCLU; on the contrary in the hyperplastic endometrial tissue with cytological atypia (AH) the sCLU expression was higher $(413 \pm 13 \%)$ than nCLU. In both tissues $(\mathrm{H}$ and $\mathrm{AH})$ the isoform 11036 was comparable to nCLU $(104 \pm 5 \%$ and $115 \pm 4 \%$, respectively). In the neoplastic endometrial tissues (K) both the 
A

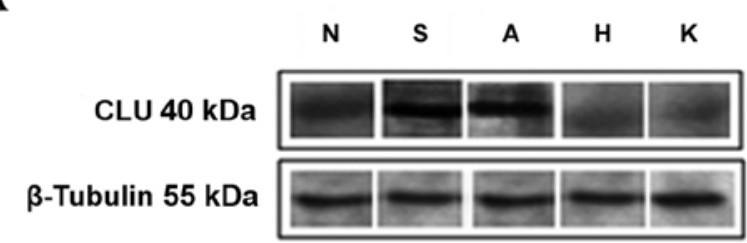

\section{B}

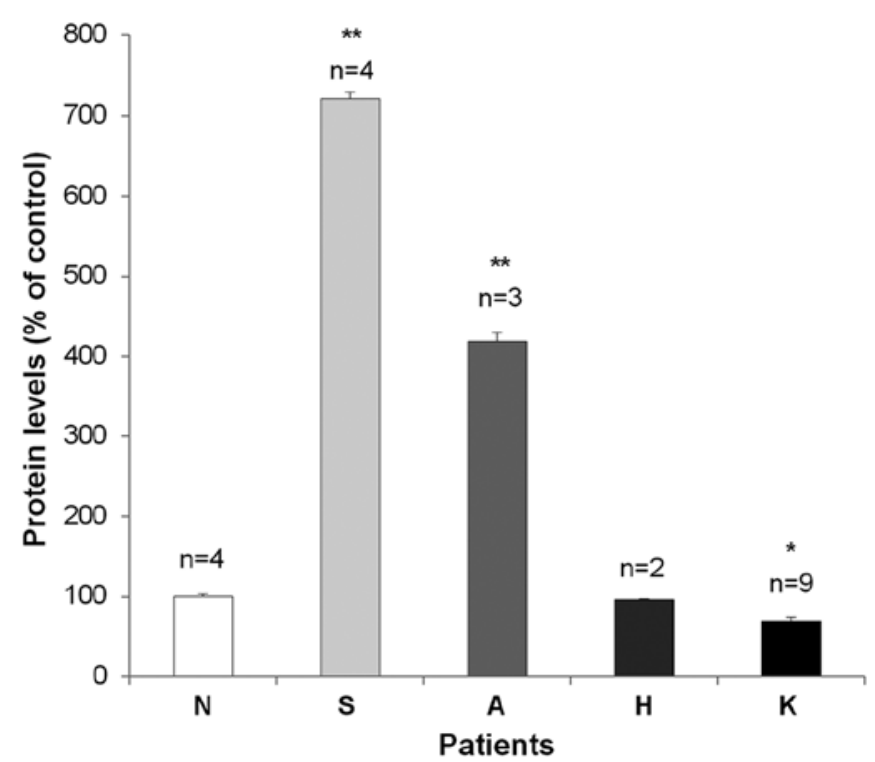

Figure 5. CLU protein expression in the endometrial tissues. (A) The autoradiographies for one representative normal proliferative $(N)$, secretive $(S)$, atrophic (A), hyperplasia $(\mathrm{H})$ and neoplastic $(\mathrm{K})$ endometria, by western blot are shown. To normalize the amount of total proteins in each sample, the blot was stripped and re-incubated again using an antibody anti- $\beta$-tubulin. (B) The average of CLU protein levels in secretive (S), atrophic (A), hyperplasia $(\mathrm{H})$ and neoplastic $(\mathrm{K})$ endometrial tissues was calculated as the percentage of normal proliferative endometria $(\mathrm{N})$. Mean values \pm SEM from two different experiments are reported. Error bars indicate SEM. ${ }^{*} \mathrm{P}<0.05 ;{ }^{* *} \mathrm{P}<0.01$.

sCLU and isoform 11036 mRNA were higher $(396 \pm 11 \%$ and $1,939 \pm 25 \%$ ) when compared to the nCLU.

These results indicate a shift in the CLU mRNA expression from the pro-apoptotic nCLU to the cytoprotective-oncogenic sCLU isoform during the transition from normal to malignant cell in the neoplastic transformation process. Concerning isoform 11036, our results show for the first time that it is expressed in all endometrial phases, whereas further experiments are necessary to clarify its role, its expression is differentially regulated in the physio-pathological endometrial stages.

$C L U$ protein expression in endometrial tissues. To clarify the role of CLU during the neoplastic cell transformation, we measured its protein level by western blot analysis (Fig. 5). Since specific antibodies for each isoforms are not available we could not evaluate the different protein CLU variants but the $\alpha$ subunit of the CLU heterodimer was recognized by the (clone 41D) antibody that is a monoclonal anti-human CLU (Upstate Cell Signaling Solutions). After normalization with
A

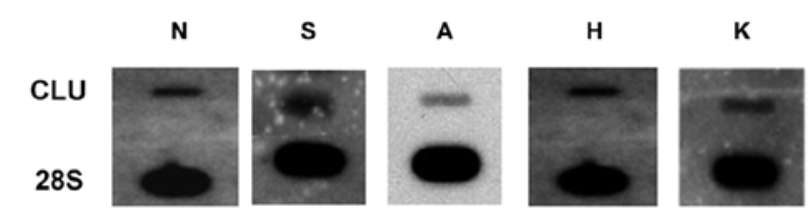

B

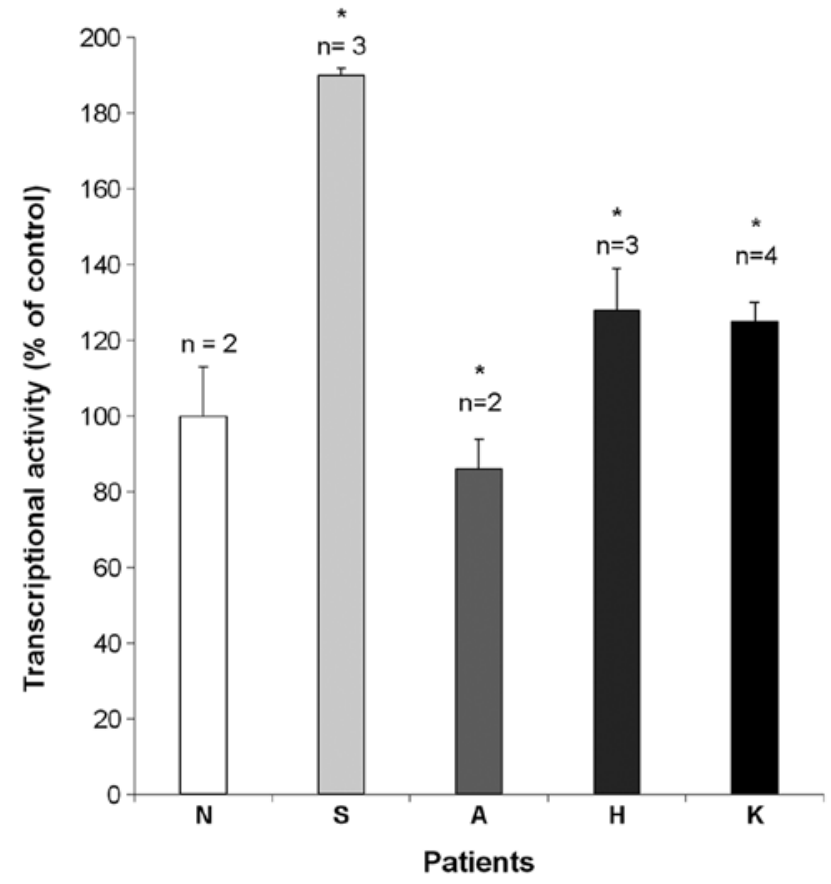

Figure 6. CLU gene transcriptional activity in the endometrial tissues. (A) The autoradiographies for one representative normal proliferative $(\mathrm{N})$, secretive $(\mathrm{S})$, atrophic (A), hyperplasia $(\mathrm{H})$ and neoplastic $(\mathrm{K})$ endometria by run-on experiments are shown. (B) For each specimen, the CLU transcriptional activity was normalized to the internal standard 28S rRNA, and transcriptional activity in secretive (S), atrophic (A), hyperplasia $(\mathrm{H})$ and neoplastic $(\mathrm{K})$ endometrial tissues was calculated as the percentage of the normal proliferative endometrial specimens $(\mathrm{N})$. Mean values \pm SEM from two different experiments are shown. Error bars indicate SEM. ${ }^{*} \mathrm{P}<0.05$

$\beta$-tubulin protein expression, the mean value of at least three separate measurements for each patient were recorded and the CLU protein level (average \pm SEM) was calculated as percentage of normal proliferative endometrium. Upregulated CLU protein levels were detected in secretive $(721 \pm 1 \%)$ and atrophic $(410 \pm 1 \%)$ endometrial samples, in comparison to the proliferative endometria. In the secretive tissues (S) CLU expression ranged between $601 \pm 1 \%$ and $928 \pm 1 \%$; in the atrophic tissues (A) the CLU expression ranged between $132 \pm 1 \%$ and $808 \pm 1 \%$. These increases resulted statistically significant $(\mathrm{p}<0.01)$ in comparison with control.

In the neoplastic tissue $(\mathrm{K})$ a statistically significant $(\mathrm{p}<0.05)$ decrease of CLU protein level $(70 \pm 1 \%)$ was measured in comparison to the proliferative endometrium, ranging between $29 \pm 1 \%$ and $109 \pm 1 \%$. No alteration was found in the hyperplastic tissues (H): CLU protein ranged between $91 \pm 1 \%$ and $101 \pm 1 \%$. We observed a direct correlation $(r=0.97 ; p=0.035)$ between protein and mRNA CLU levels in the secretive and atrophic endometrial tissue suggesting a possible transcriptional mechanism of regulation. The indirect correlation $(r=-0.93 ; p=0.005)$ 
Table II. CLU immunoreactivity in the endometrial tissues.

\begin{tabular}{|c|c|c|c|c|c|c|}
\hline $\begin{array}{l}\text { Tissue type } \\
\text { (no. of patients) }\end{array}$ & $\begin{array}{c}\text { Range of } \\
\text { IR superficial } \\
\text { epithelial cells } \\
(\%)\end{array}$ & $\begin{array}{c}\text { Median of } \\
\text { IR superficial } \\
\text { epithelial cells } \\
(\%)\end{array}$ & $\begin{array}{c}\text { Range of } \\
\text { IR glandular } \\
\text { epithelial cells } \\
(\%)\end{array}$ & $\begin{array}{l}\text { Median of } \\
\text { IR glandular } \\
\text { epithelial cells } \\
\text { (\%) }\end{array}$ & $\begin{array}{c}\text { Range of IR } \\
\text { stromal cells } \\
(\%)\end{array}$ & $\begin{array}{c}\text { Median of IR } \\
\text { stromal cells } \\
(\%)\end{array}$ \\
\hline $\begin{array}{l}\text { Normal proliferative } \\
\text { endometrium }(n=7)\end{array}$ & $0-10$ & 0 & $0-90$ & 0 & $0-40$ & 20 \\
\hline $\begin{array}{l}\text { Secretive } \\
\text { endometrium }(n=5)\end{array}$ & $0-50$ & 2 & $5-50$ & 35 & 4-10 & 5 \\
\hline $\begin{array}{l}\text { Atrophic } \\
\text { endometrium }(n=6)\end{array}$ & $0-20$ & 5 & $10-95$ & 40 & $0-20$ & 0 \\
\hline $\begin{array}{l}\text { Simple } \\
\text { hyperplasia }(n=6)\end{array}$ & $0-30$ & 0 & $0-75$ & 30 & $0-25$ & 2 \\
\hline $\begin{array}{l}\text { Atypical } \\
\text { hyperplasia }(n=4)\end{array}$ & $0-30$ & 4 & $0-75$ & 35 & $0-25$ & 5 \\
\hline $\begin{array}{l}\text { Endometrioid } \\
\text { adenocarcinoma }(n=9)\end{array}$ & $0-20$ & 2 & $0-90$ & 20 & $\begin{array}{c}0 \text { (in all } \\
\text { sections } \\
\text { analyzed) }\end{array}$ & 0 \\
\hline
\end{tabular}

IR, immunoreactive.

between CLU protein and mRNA level in both carcinoma and hyperplasia, suggests a post-transcriptional regulation, possibly involving mRNA turn-over and/or protein synthesis.

Transcriptional regulation of $C L U$ expression. To investigate the possible molecular mechanisms implicated in the regulation of CLU expression, we measured the transcriptional activity of the CLU gene by nuclear run-on assays. The autoradiographic signals obtained in a typical run-on experiment carried out using one representative normal proliferative endometrium $(\mathrm{N})$, one secretive $(\mathrm{S})$, one atrophic $(\mathrm{A})$, one neoplastic $(\mathrm{K})$ and one hyperplastic $(\mathrm{H})$ sample, are shown in Fig. 6A. The semi-quantitative analysis of the autoradio-

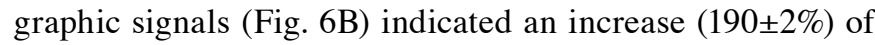
CLU transcriptional activity in normal secretive endometrial tissues (S), in comparison to the normal proliferative tissues $(\mathrm{N})$. Although these results need to be verified in a larger population, they seem to indicate that the CLU gene transcriptional activity may possibly be responsible for the CLU mRNA upregulation.

On the contrary, the gene transcriptional activity is not responsible by itself for CLU mRNA increase measured in the atrophic tissues (A) since CLU transcriptional activity was downregulated $(86 \pm 8 \%)$ in comparison to the normal proliferative tissues $(\mathrm{N})$. In the neoplastic $(\mathrm{K})$ endometrial tissues CLU transcriptional activity ranged between $104 \pm 2 \%$ and $144 \pm 8 \%$, showing a statistically significant $(\mathrm{p}<0.05)$ increase $(125 \pm 5 \%)$ when compared to the proliferative endometrial tissues. Moreover, we demonstrated a statistically significant $(\mathrm{p}<0.05)$ increase of CLU transcriptional activity $(128 \pm 13 \%)$ in the endometrial hyperplasia $(\mathrm{H})$ in comparison to the proliferative endometrial tissue $(\mathrm{N})$.

The above results seem to indicate that CLU transcriptional activity may be responsible for mRNA increase in both carcinoma and hyperplasia. Since the CLU protein levels do not correlate to the CLU mRNA level, the results from run-on experiments suggest the existence of a fine regulatory mechanism of CLU protein expression in the neoplastic disease possibly acting at post-transcriptional level.

CLU immunohistochemistry. CLU immunoreactivity, carried out using the antibody described above, was evaluated in 7 proliferative, 5 secretive, 6 atrophic endometria, 6 simple and 4 hyperplasias with atypia and in 8 endometrial carcinomas (see Table I). Fig. 7 shows the hematoxylin and eosin (A, C, E, G, I, K) and the corresponding ABC immonohistochemical (B, D, F, H, J, L) microscopical features of the different endometrial conditions. CLU immunoreactivity was more intense in the glandular basal cells, in comparison to the superficial epithelial and stromal cells. Moreover, anti-CLU antibody largely shows positive staining in the cytoplasm of all sections, as reported in previous studies documenting the CLU localization in the cytoplasm of breast, prostate and ovarian tissues $(7,9,45)$. Table II reports the descriptive analysis of CLU immunoreactivity in the different cellular compartments of the various endometrial tissue sections. The number of immunoreactive cells was higher in the glandular basal cells than the superficial epithelial and stromal cells of the normal (F, proliferative; $\mathrm{S}$, secretive; and $\mathrm{A}$, atrophic) proliferative endometrium. Moreover, comparing normal and neoplastic endometrial tissue we observed prevalent CLU expression in the glandular epithelial compartment. The CLU expression in the neoplastic tissue was downregulated in both epithelial (glandular and superficial) and stromal cells in comparison to the physiological conditions (proliferative, secretive and atrophic endometrial tissue). CLU immunoreactivity in the hyperplastic endometrial tissues does not show a significant difference between hyperplastic endometrial tissue without 

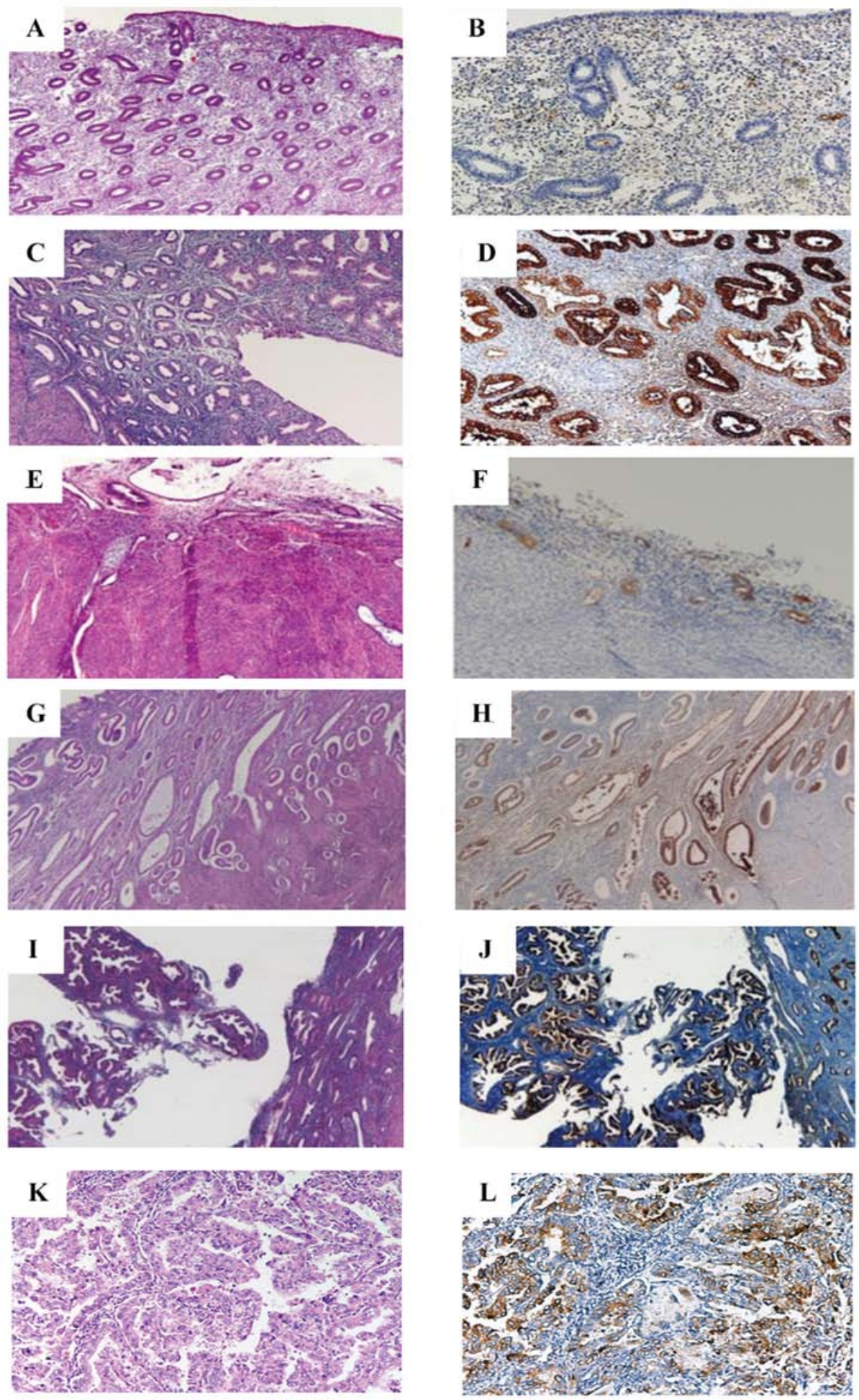

Figure 7. CLU immunoreactivity in the endometrial tissues. (A) Normal proliferative endometria, hematoxylin and eosin (H\&E) x4. (B) Normal proliferative endometria (ABC immunohistochemical technique x10). (C) Secretive endometria, H\&E x4. (D) Secretive endometria (ABC immunohistochemical technique x10). (E) Atrophic endometria, H\&E x4. (F) Atrophic endometria (ABC immunohistochemical technique x10). (G) Simple endometrial hyperplasia, H\&E x2. (H) Simple endometrial hyperplasia (ABC immunohistochemical technique x2). (I) Endometrial hyperplasia with cytological atypia, H\&E x2. (J) Endometrial hyperplasia with cytological atypia (ABC immunohistochemical technique x2). (K) Neoplastic endometria, H\&E x10; (L) Neoplastic endometria (ABC Immunohistochemical technique x10).

cytological atypia $(\mathrm{H})$ and with cytological atypia $(\mathrm{AH})$, confirming the protein results obtained by western blot analysis, suggesting a benign proliferative origin for the hyperplastic disease.
As the statistical analysis were not powerful enough, due to the limited number of investigated cases $(\mathrm{G} 1=3, \mathrm{G} 2=4$, $\mathrm{G} 3=2$ and stage $\mathrm{I}=7$, stage $\mathrm{II}=1$, stage $\mathrm{III}=1$ ), we could not demonstrate any correlation between CLU expression and 
tumor grade and stage in endometrial carcinomas. Since, the monoclonal antibody (clone 41D) recognizes the $\alpha$ subunit of the CLU heterodimer, we can suggest a key role for the sCLU isoform in endometrial carcinogenesis probably acting by cytoprotective and anti-apoptotic pathways. To confirm this hypothesis we examined epithelial cell apoptosis using anti-caspase-3 antibody. Immunohistochemical analysis demonstrated that caspase-3 protein expression is absent within the nuclei of all the epithelial endometrial cells of our samples (data not shown) thus confirming the anti-apoptotic role of CLU.

\section{Discussion}

Although several molecules may be associated with endometrial carcinogenesis, their role in malignant transformation has not yet been well established. We have previously focused our attention on the role of growth factors and adhesion factors in the aetiopathogenesis of human proliferative diseases providing the first evidence of a transcriptional and post-transcriptional in vivo regulation of the expression of these factors during cellular transformation leading to the malignant phenotype (22-36). Among these, CLU is an enigmatic glycoprotein with a nearly ubiquitous tissue distribution and an apparent involvement in biological processes ranging from neurodegeneration in Alzheimer's disease to cancer initiation and progression. It exists in at least two protein variants, secreted and truncated forms. The secreted form of CLU is implicated in a variety of activities such as programmed cell death, regulation of complement mediated cell lysis, membrane recycling, cell-cell adhesion and transformation; the nuclear isoform acts as a pro-death signal, inhibiting cell survival. It has been previously shown that CLU plays a key role in the cell transformation process, and it has been reported to be overexpressed in several human tumour tissues such as prostate, breast, renal, ovarian, colon, cervix, lung and anaplastic large cell lymphoma (9-16). Upregulation of CLU mRNA and protein are widespread phenomena in developmental and patho-physiological states, suggesting that control of expression levels is important. Increased expression of CLU has been established in diseases where either abnormal cell death or proliferation is occurring (18). Despite the growing evidence for a role of CLU in the aetiology of cancer in various tissues, the regulation of its expression and function in human endometrial carcinoma is not well established.

We have demonstrated in this paper for the first time that CLU mRNA expression is upregulated in human endometrial carcinoma in vivo, when compared with normal proliferative endometrial tissues. Our results are in agreement with the data from other laboratories showing increased CLU mRNA expression in hormonally regulated cancers such as human prostate (7) and breast carcinoma (9). In both cases the upregulation of CLU mRNA was associated with increased cancer cell survival, suggesting that CLU overexpression may contribute to the increase of tumour cell survival. Moreover, to investigate the possible use of CLU as prognostic marker to predict the clinical progression of endometrial cancer disease, we investigated the possible involvement of CLU in the clinical progression of endometrial proliferative diseases. Even if our preliminary results need to be verified in a larger and more representative population, we observed a progressive general
CLU mRNA increase with increasing tumour grade, reaching its peak in poorly differentiated (G3) endometrial cancer, suggesting a possible direct correlation between CLU mRNA expression and tumour grade.

We also investigated the role of CLU during the physiological changes of uterine tissues throughout the menstrual cycle. The semi-quantitative analysis of northern hybridization experiments showed an increased steady-state CLU mRNA levels in both secretive and atrophic endometrial samples when compared to the proliferative tissue.

Our results are in agreement with previous data (46), showing that CLU is expressed in human endometrium during the secretive phase of menstrual cycle, probably playing a cytoprotective role. Other experimental data showed CLU overexpression in normal cells, such as human prostate epithelial cells (47) and quiescent normal skin fibroblasts (48), suggesting that CLU gene expression may play a key role in the regulation of cell cycle progression. Apparently, the results of immunohistochemical stains do not recapitulate those obtained with different technical procedures. It should be emphasized that immunohistochemistry is not intended as a quantitative method and that, even though an attempt was done to semi-quantitatively evaluate the number of immunoreactive cells in different cell compartments of the endometrium, the results of such attempts should be primarily evaluated to assess the cell types involved in CLU production and accumulation (i.e., glandular epithelial cells vs. superficial epithelial cells and stromal cells). In fact, both the intensity of staining and the number of immunoreactive cells do not adequately recapitulate the functional activities of the cells and should not be used as a direct support to the results of the many other molecular techniques used in this study. Furthermore, we demonstrated here for the first time the CLU mRNA upregulation in the hyperplastic endometrial diseases and this increase was higher in the hyperplasia with atypia than in the simple hyperplasia, suggesting that CLU may protect cells from death also in non-malignant proliferative lesions and this anti-apoptotic function is higher in the less benign proliferation state of disease.

Our data demonstrate that CLU mRNA expression is upregulated in human endometrial hyperplasia and carcinoma in comparison to the normal tissue, thus providing the first circumstantial evidence for the possible use of CLU as a new potential biomarker for endometrial proliferative diseases.

Since up to now experimental evidence seems to indicate that a balance of sCLU:nCLU ratio in the cell dictates its fate and is critical for cancer survival and progression, we analyzed the balance between the CLU isoforms in the different physiopathological conditions to possibly identify a specific association among CLU isoforms and different endometrial conditions. RT-qPCR experiments demonstrated a differential expression of the nCLU, sCLU and isoform 11036 in the different endometrial tissues and a comparison among physiological and pathological conditions was carried out. Changes of nCLU mRNA expression were observed in the physiological endometrial tissues, probably depending on the hormonal regulation during the uterine cycle. The nCLU mRNA expression is downregulated in the secretive tissue, in comparison to the follicular tissue. nCLU is known to be downregulated during the anchoring of cells to the extracellular matrix (ECM) $(49,50)$. Since the secretive endometrial tissue is a well differentiated tissue, with 
relatively little tendency to proliferate and strong interactions with the ECM, the downregulation of the nCLU, which inhibits the formation of cross-linked actin filaments by binding the $\alpha$-actinin, prevents the disassembly of the cytoskeleton, peculiar of a cell with a low differentiation degree that meet the rapid cycles of division and death.

Furthermore, we demonstrated an upregulation of nCLU mRNA in the atrophic endometrial tissues, which is typical physiological involution of post-menopausal stage caused by the estrogens decrease, presenting a thin epithelium with the glandular component layer absent. Normal cells require adhesion to the ECM to survive, and inadequate interaction can lead to anoikis (51). An increase of nCLU mRNA would determine the formation of specific ties with the $\alpha$-actinin, resulting in cytoskeletal disruption, non-adhesion of cells to ECM and low proliferative capacity, induction of cell cycle arrest and a tendency to death, characteristics of a typical atrophic endometrial tissue. The downregulation of nCLU mRNA observed in the endometrial cancer tissues agrees with most studies reported in the literature, which show loss of expression of this isoform in advanced cancer (52). As already shown in other human cancers, endometrial cancer cells downregulate the nCLU expression, which leads to altered cell death pathway and does not imply nCLU/Ku70-Ku80 complex formation, the latter being necessary to eliminate cancer cells (53). The upregulation of nCLU mRNA measured in the hyperplastic endometrial tissue samples suggests an hormonal dependence of its expression, confirmed by the detection of increased nCLU mRNA levels during the transition from hyperplasia without atypia to hyperplasia with cytologic atypia. This result seems to attest a benign proliferative origin for the hyperplastic disease even in the presence of atypia, whereas it was demonstrated (41) that $30 \%$ of cases of hyperplasia with atypia evolve in endometrial carcinoma. The low level of sCLU mRNA expression observed in the secretive phase suggests a reduction of the pro-proliferative isoform during the transition to a more differentiated cell state. Indeed, during the secretive phase, endometrium continues to grow thick while ceasing proliferation of epithelial cells due to the cytostatic effect of progesterone.

Our RT-qPCR experiments show a sCLU increase in atrophic endometrial tissue, a non-proliferative and quiescent tissue (G0 phase of the cell cycle) confirming the essential role of this isoform in the cell cycle regulation (4). This result is in agreement with the accumulation of sCLU in the G0 phase of cell cycle reported in the human and murine fibroblasts under conditions of quiescence and senescence (54-56). Transient overexpression of CLU in human prostate cells immortalized with SV40, caused blockage of G0/G1 progression with a reduction of DNA synthesis $(6,57,58)$.

We demonstrated the upregulation of the sCLU mRNA expression in the neoplastic endometrium, thus confirming its role as oncogene, consistent with data reported for other tumours such as prostate (7,53-55), breast (9), lung (12), colon (8-11), ovary (14) cancers. The 11036 isoform was recently characterized in the colon cancer (8), however, its functional role remains unclear. Our RT-qPCR experiments indicate its presence in the different endometrial tissues, further studies will be necessary to clarify its role in the endometrial physiopathology. To provide data on the variation of expression of each CLU isoforms in the different physiological and pathological endometrial tissue, it was analyzed in these three isoforms in the different endometrial conditions. The measure of this ratio may allow us to identify a specific role of one of the CLU variants in the transition from the physiological to the pathological stage.

The results of our experiments suggest a trend toward the prevalence of the sCLU in the endometrial carcinoma with respect to the nCLU suggesting that the cytoprotective sCLU isoform is probably preferentially retained in the cytosol of cancer cells, promoting cell survival. The synthesis of the two sCLU and nCLU isoforms may therefore play a crucial role in controlling the balance between proliferation and cell death, strongly influencing the cell life. The neoplastic transformation is featured by the alteration of this mechanism with a dominance of the sCLU respect to the nCLU, thus promoting survival of transformed cells. This hypothesis is in agreement with previous studies, suggesting that the survival of cancer cells is related to an overexpression of sCLU and a downregulation of nCLU (40). To better clarify the role of CLU during the neoplastic cell transformation, we measured CLU protein level in the endometrial tissues, even if it is not possible to evaluate the different CLU variants as specific antibodies for the different isoforms are still not available. The CLU protein expression measured by western blot analysis in the secretive and atrophic tissue samples was upregulated in comparison to the normal follicular tissue. On the contrary, CLU protein expression level in hyperplastic and neoplastic tissue was downregulated in comparison to the normal tissue. Whereas our results on CLU protein expression in neoplastic endometrial tissues appear to differ from those reported by Ahn et al (21), the differences could be explained by the heterogeneity of the cases.

To investigate the molecular mechanisms responsible for the regulation of CLU expression, we carried out in vivo transcriptional assays by means of run-on experiments. Even if these results need to be verified in a larger and more representative population, we concluded that CLU transcriptional activity may be partially responsible for increased CLU mRNA levels in the normal secretive and atrophic endometrial tissue. The results of run-on analysis in both neoplastic and hyperplastic tissues show the existence of a post-transcriptional regulation of CLU expression possibly involving the mRNA turn-over and/or protein synthesis. Since in previous studies CLU was localized mostly in the cytoplasm of breast, prostate and ovarian normal and neoplastic tissues $(7,9,14)$, we decided to investigate the CLU protein expression and its sub-cellular localization by immunohistochemical analysis. These results are in agreement with other studies conducted in ovarian cancer (45). Our results show a positive CLU immunoreactivity in the glandular cells of all endometrial tissue samples in comparison to the epithelial and stromal cells where the CLU immunoreactivity was lower or absent. The prevalent CLU expression in the epithelial compartment, in agreement with data from others laboratories, suggests that the CLU expression would play a cytoprotective role in a large variety of epithelia other than endometria, such as esophagus, urethra and rete testis epithelial cells (4). In agreement with this hypothesis, we observed absence of the caspase- 3 expression, suggesting that the sCLU variant probably contributes to the ability of malignant cells to evade apoptosis. Since caspase-3 has been identified as being a key mediator of mammalian cell 
apoptosis and loss of its expression is thought to contribute to the capability of malignant cells to evade apoptosis, the CLU-mediated endometrial proliferation induction probably proceeds via caspase-3 inactivation, such as in prostate cancer $(17,18)$. Our findings indicate that CLU is a cell survival gene upregulated by apoptotic triggers, and confers resistance when overexpressed, thereby suggesting the potential use of CLU as a therapeutic target for cancer (18).

Our results provide important new insights into the timing and molecular nature of the critical events involved in endometrial carcinogenesis and may turn out useful in the design of improved surveillance strategies for endometrial carcinoma in the future. Moreover, the shift of sCLU:nCLU towards sCLU is critical for endometrial cancer survival and progression, providing a novel biomarker for this malignancy. Since the suppression of the sCLU isoform expression renders human cancer cells sensitive to chemotherapeutic drug-mediated apoptosis, and it is currently an antisense target in clinical trials for prostate cancer, the long-term objective of our studies is to state CLU as a new targeted modulator of endometrial cell proliferation potentially useful to generate rationally designed drugs based on tissue specific expression, in order to control cancer cell proliferation.

\section{Acknowledgements}

This study was supported by the FIRB-MERIT RBNE08YFN3_005 and PON01_01297 R\&C 2007-2013, VIRTUALAB by MIUR. The authors wish to thank Giuseppe Cananzi for technical assistance.

\section{References}

1. Oehler MK, Brand A and Wain GV: Molecular genetics and endometrial cancer. J Br Menopause Soc 9: 27-31, 2003.

2. Wunsche W, Tenniswood MP, Schneider MR and Vollmer G: Estrogenic regulation of clusterin mRNA in normal and malignant endometrial tissue. Int J Cancer 76: 684-688, 1998.

3. Rosenberg ME and Silkensen J: Clusterin: physiologic and pathophysiologic considerations. Int J Biochem Cell Biol 27: 633-645, 1995.

4. Shannan B, Seifert M, Leskov K, Willis J, Boothman D, Tilgen W and Reichrath J: Challenge and promise: roles for clusterin in pathogenesis, progression and therapy of cancer. Cell Death Differ 13: 12-19, 2006.

5. Trougakos IP, Lourda M, Agiostratidou G, Kletsas D and Gonos ES: Differential effects of clusterin/apolipoprotein J on cellular growth and survival. Free Radic Biol Med 38: 436-449, 2005.

6. Scaltriti M, Santamaria A, Paciucci R and Bettuzzi S: Intracellular clusterin induces $\mathrm{G} 2-\mathrm{M}$ phase arrest and cell death in PC-3 prostate cancer cells. Cancer Res 64: 6174-6182, 2004.

7. Scaltriti M, Bettuzzi S, Sharrard RM, Caporali A, Caccamo AE and Maitland NJ: Clusterin overexpression in both malignant and nonmalignant prostate epithelial cells induces cell cycle arrest and apoptosis. Br J Cancer 91: 1842-1850, 2004.

8. Andersen CL, Schepeler T, Thorsen K, et al: Clusterin expression in normal mucosa and colorectal cancer. Mol Cell Proteomics 6: 1039-1048, 2007.

9. Redondo M, Villar E, Torres-Munoz J, Tellez T, Morell M and Petito CK: Overexpression of clusterin in human breast carcinoma. Am J Pathol 157: 393-399, 2000.

10. Kurahashi T, Muramaki M, Yamanaka K, Hara I and Miyake H: Expression of the secreted form of clusterin protein in renal cell carcinoma as a predictor of disease extension. BJU Int 96 : 895-899, 2005

11. Pucci S, Bonanno E, Pichiorri F, Angeloni C and Spagnoli LG: Modulation of different clusterin isoforms in human colon tumorigenesis. Oncogene 23: 2298-2304, 2004.
12. July LV, Beraldi E, So A, Fazli L, Evans K, English JC and Gleave ME: Nucleotide-based therapies targeting clusterin chemosensitize human lung adenocarcinoma cells both in vitro and in vivo. Mol Cancer Ther 3: 223-232, 2004.

13. Scaltriti M, Brausi M, Amorosi A, et al: Clusterin (SGP-2, ApoJ) expression is downregulated in low- and high-grade human prostate cancer. Int J Cancer 108: 23-30, 2004.

14. Hassan MK, Watari H, Han Y, et al: Clusterin is a potential molecular predictor for ovarian cancer patient's survival: targeting Clusterin improves response to paclitaxel. J Exp Clin Cancer Res 113: 1-14, 2011.

15. Watari H, Ohta Y, Hassan MK, Xiong Y, Tanaka S and Sakuragi N: Clusterin expression predicts survival of invasive cervical cancer patients treated with radical hysterectomy and systematic lymphadenectomy. Gynecol Oncol 108: 527-532, 2008.

16. Wellmann A, Thieblemont C, Pittaluga S, Sakai A, Jaffe ES, Siebert P and Raffeld M: Detection of differentially expressed genes in lymphomas using cDNA arrays: identification of clusterin as a new diagnostic marker for anaplastic large-cell lymphomas. Blood 96: 398-404, 2000.

17. Moretti RM, Marelli MM, Mai S, Cariboni A, Scaltriti M, Bettuzzi S and Limonta P: Clusterin isoforms differentially affect growth and motility of prostate cells: possible implications in prostate tumorigenesis. Cancer Res 67: 10325-10333, 2007.

18. Gleave M and Chi KN: Knock-down of the cytoprotective gene, clusterin, to enhance hormone and chemosensitivity in prostate and other cancers. Ann NY Acad Sci 1058: 1-15, 2005.

19. Seol MB, Bong JJ and Baik M: Expression profiles of apoptosis genes in mammary epithelial cells. Mol Cells 20: 97-104, 2005.

20. Miyake H, Hara I, Fujisawa M and Gleave ME: The potential of clusterin inhibiting antisense oligodeoxynucleotide therapy for prostate cancer. Expert Opin Investig Drugs 15: 507-517, 2006.

21. Ahn HJ, Bae J, Lee S, Ko JE, Yoon S, Kim SJ and Sakuragi N: Differential expression of clusterin according to histological type of endometrial carcinoma. Gynecol Oncol 110: 222-229, 2008.

22. Perlino E, Lovecchio M, Vacca RA, et al: Regulation of mRNA and protein levels of betal integrin variants in human prostate carcinoma. Am J Pathol 157: 1727-1734, 2000.

23. Moro L, Greco M, Ditonno P, Battaglia M, Marra E and Perlino E: Transcriptional regulation of the $\beta 1 \mathrm{C}$ integrin splice variant in human prostate adenocarcinoma. Int $\mathbf{J}$ Oncol 23: 1601-1606, 2003.

24. Perlino E, Tommasi S, Moro L, Bellizzi A, Marra E, Casavola V and Reshkin SJ: TGF- $\beta 1$ and IGF- 1 expression are differently regulated by serum in metastatic and non-metastatic human breast cancer cells. Int J Oncol 16: 155-160, 2000.

25. Maiorano E, Ciampolillo A, Viale G, et al: Insulin-like growth factor 1 expression in thyroid tumors. Appl Immunohistochem Mol Morphol 8: 110-119, 2000.

26. Perlino E, Moro L, Loverro G, Maiorano E, Selvaggi L and Marra E: Role of the growth factors IGF-1 and TGF-beta 1 in the endometrial adenocarcinoma. Int J Med Biol Env 29: 193-200, 2001

27. Vacca RA, Marra E, Loverro G, et al: Differential expression of beta 1c integrin messenger ribonucleic acid and protein levels in human endometrium and decidua during the menstrual cycle and pregnancy. J Clin Endocrinol Metab 88: 720-729, 2003.

28. Lovecchio M, Maiorano E, Vacca RA, et al: Beta 1C integrin expression in human endometrial proliferative diseases. Am J Pathol 163: 2543-2553, 2003.

29. Tommasi S, Fedele V, Lacalamita R, Crapolicchio A, Perlino E, Bellizzi A and Paradiso A: Molecular and functional characteristics of erbB2 in normal and cancer breast cells. Cancer Lett 209: 215-222, 2004.

30. Vacca RA, Moro L, Maiorano E, Selvaggi L, Marra E and Perlino E: Alternatively spliced variants of b1 integrin are involved in the modulation of human endometrial transformation in different physiological/pathological conditions. Recent Res Devel Proteins 2: 25-47, 2004.

31. Ciampolillo A, De Tullio C, Perlino E and Maiorano E: The IGF-I axis in thyroid carcinoma. Curr Pharm Des 13: 729-735, 2007.

32. Moro L, Perlino E, Marra E, Languino LR and Greco M: Regulation of beta1C and beta1A integrin expression in prostate carcinoma cells. J Biol Chem 279: 1692-1702, 2004.

33. Moro L, Greco M, Maiorano E, Selvaggi L, Marra E and Perlino E: Transcriptional regulation of $\beta 1$ integrin expression in the physio/pathological states of human endometrial tissues. Int J Oncol 26: 457-465, 2005 
34. Fuzio P, Lucarelli G, Perlino E, Battaglia M, Bettocchi C, Selvaggi FP and Ditonno P: Androgen deprivation therapy regulation of $\beta 1 \mathrm{C}$ integrin expression in prostate cancer. Oncol Rep 22: 327-335, 2009.

35. Fuzio P, Ditonno P, Lucarelli G, Battaglia M, Trabucco S and Perlino E: Androgen deprivation therapy affects BCL-2 expression in human prostate cancer. Int J Oncol 39: 1233-1242, 2011.

36. Fuzio P, Ditonno P, Rutigliano M, et al: Regulation of TGF- $\beta 1$ expression by androgen deprivation therapy of prostate cancer. Cancer Lett 318: 135-144, 2012.

37. Benedet JL, Bender H, Jones H, Ngan HY and Pecorelli S: FIGO staging classifications and clinical practice guidelines in the management of gynecologic cancers. FIGO Committee on Gynecologic Oncology. Int J Gynaecol Obstet 70: 209-262, 2000.

38. Bhatia P, Taylor WR, Greenberg AH and Wright JA: Comparison of glyceraldehyde-3-phosphate dehydrogenase and 28S-ribosomal RNA gene expression as RNA loading controls for northern blot analysis of cell lines of varying malignant potential. Anal Biochem 216: 223-226, 1994.

39. Peirson SN, Butler JN and Foster RG: Experimental validation of novel and conventional approaches to quantitative real-time PCR data analysis. Nucleic Acids Res 31: e73, 2003.

40. Rizzi F and Bettuzzi F: The clusterin paradigm in prostate and breast carcinogenesis. Endocr Relat Cancer 17: R1-R17, 2010.

41. Nieminen TT, Gylling A, Abdel-Rahman WM, et al: Molecular analysis of endometrial tumorigenesis: importance of complex hyperplasia regardless of atypia. Clin Cancer Res 15: 5772-5783, 2009.

42. Castrignanò T, D'Antonio M, Anselmo A, et al: ASPicDB: a database resource for alternative splicing analysis. Bioinformatics 24: 1300-1304, 2008.

43. Martelli PL, D'Antonio M, Bonizzoni P, et al: ASPicDB: database of annotated transcript and protein variants generated by alternative splicing. Nucleic Acids Res 39: D80-D85, 2011

44. Riva A and Pesole G: A unique, consistent identifier for alternatively spliced transcript variants. PLoS One 4: e7631, 2009.

45. Xie D, Lau SH, Sham JS, et al: Up-regulated expression of cytoplasmic clusterin in human ovarian carcinoma. Cancer 103: 277-283, 2005

46. Brown TL, Moulton BC, Baker VV, Mira J and Harmony JA Expression of apolipoprotein $\mathrm{J}$ in the uterus is associated with tissue remodeling. Biol Reprod 52: 1038-1049, 1995.

47. Bettuzzi S, Scorcioni F, Astancolle S, Davalli P, Scaltriti M and Corti A: Clusterin (SGP-2) transient overexpression decreases proliferation rate of SV40-immortalized human prostate epithelial cells by slowing down cell cycle progression. Oncogene 21 : 4328-4334, 2002.
48. Bettuzzi S, Astancolle S, Guidetti G, Moretti M, Tiozzo R and Corti A: Clusterin (SGP-2) gene expression is cell cycle dependent in normal human dermal fibroblasts. FEBS Lett 448: 297-300, 1999.

49. Goldberg GS, Jin Z, Ichikawa H, Naito A, Ohki M, El-Deiry WS and Tsuda H: Global effects of anchorage on gene expression during mammary carcinoma cell growth reveal role of tumor necrosis factor-related apoptosis-inducing ligand in anoikis. Cancer Res 61: 1334-1337, 2001.

50. Caccamo AE, Desenzani S, Belloni L, Borghetti AF and Bettuzzi S: Nuclear clusterin accumulation during heat shock response: implications for cell survival and thermotolerance induction in immortalized and prostate cancer cells. J Cell Physiol 207: 208-219, 2006.

51. Frisch SM and Screaton RA: Anoikis mechanisms. Curr Opin Cell Biol 13: 555-562, 2001

52. Trougakos IP, Djeu JY, Gonos ES and Boothman DA: Advances and challenges in basic and translational research on clusterin. Cancer Res 69: 403-406, 2009.

53. Yang CR, Leskov K, Hosley-Eberlein K, Criswell T, Pink JJ, Kinsella TJ and Boothman DA: Nuclear clusterin/XIP8, an $\mathrm{X}$-ray-induced $\mathrm{Ku} 70$-binding protein that signals cell death. Proc Natl Acad Sci USA 97: 5907-5912, 2000.

54. Petropoulou C, Trougakos IP, Kolettas E, Toussaint $\mathrm{O}$ and Gonos ES: Clusterin/apolipoprotein $\mathrm{J}$ is a novel biomarker of cellular senescence that does not affect the proliferative capacity of human diploid fibroblasto. FEBS Lett 509: 287-297, 2001.

55. Gonos ES, Derventzi A, Kveiborg M, Agiostratidou G, Kassem M, Clark BF, Jat PS and Rattan SI: Cloning and identification of genes that associate with mammalian replicative senescence. Exp Cell Res 240: 66-74, 1998.

56. Miyake H, Hara I, Kamidono S, Gleave ME and Eto $\mathrm{H}$ : Resistance to cytotoxic chemotherapy-induced apoptosis in human prostate cancer cells is associated with intracellular clusterin expression. Oncol Rep 10: 469-473, 2003.

57. Miyake H, Hara I, Gleave ME and Eto H: Protection of androgen-dependent human prostate cancer cells from oxidative stress-induced DNA damage by overexpression of clusterin and its modulation by androgen. Prostate 61: 318-323, 2004.

58. Zellweger T, Kiyama S, Chi K, Miyake H, Adomat H, Skov K and Gleave ME: Overexpression of the cytoprotective protein clusterin decreases radiosensitivity in the human LNCaP prostate tumour model. BJU Int 92: 463-469, 2003. 